
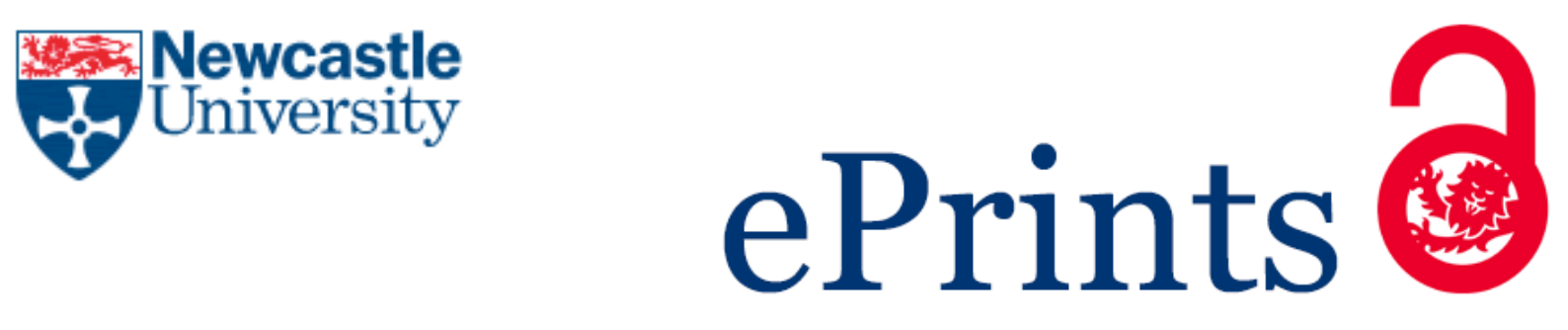

Damon CA, Gatley CM, Beres JJ, Finlay JA, Franco SC, Clare AS, Detty MR. The performance of hybrid titania/silica-derived xerogels as active antifouling/fouling-release surfaces against the marine alga Ulva linza: in situ generation of hypohalous acids.

Biofouling 2016, 32(8), 883-896.

\title{
Copyright:
}

This is an Accepted Manuscript of an article published by Taylor \& Francis in Biofouling on 26/07/2016, available online: http://www.tandfonline.com/10.1080/08927014.2016.1203420

DOI link to article:

http://dx.doi.org/10.1080/08927014.2016.1203420

Date deposited:

$11 / 08 / 2016$

Embargo release date:

26 July 2017

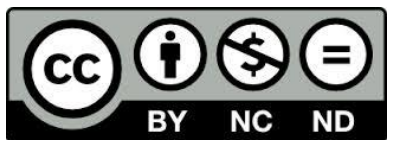

This work is licensed under a

Creative Commons Attribution-NonCommercial-NoDerivatives 4.0 International licence 


\section{The performance of hybrid titania/silica-derived xerogels as active antifouling/fouling-release surfaces against the marine alga Ulva linza: in situ generation of hypohalous acids}

Corey A. Damon, ${ }^{1}$ Caitlyn M. Gatley, ${ }^{1}$ Joshua J. Beres, ${ }^{1}$ John A. Finlay, ${ }^{2}$ Sofia C. Franco, ${ }^{2}$ Anthony S. Clare, ${ }^{2}$ and Michael R. Detty ${ }^{1 *}$

${ }^{1}$ Department of Chemistry, University at Buffalo, The State University of New York, Buffalo, New York 14260-3000, USA.

${ }^{2}$ School of Marine Science and Technology, Newcastle University, Newcastle NE1 7RU, UK

* For correspondence (mdetty@,buffalo.edu)

Abstract: Mixed titania/silica xerogels were prepared using titanium tetraisopropoxide (TTIP) and tetraethoxy orthosilicate (TEOS). Xerogel properties were modified by incorporating $n$ octyltriethoxysilane (C8). The xerogels catalyze the oxidation of bromide and chloride with hydrogen peroxide $\left(\mathrm{H}_{2} \mathrm{O}_{2}\right)$ to produce hypohalous acids at $\mathrm{pH} 7$ and $\mathrm{pH}$ 8. The antifouling/ fouling-release performance of a TTIP/C8/TEOS xerogel in the presence and absence of $\mathrm{H}_{2} \mathrm{O}_{2}$ was evaluated for the settlement of zoospores of the marine alga Ulva linza and on the removal of 7-day-old sporeling biomass. In the absence of $\mathrm{H}_{2} \mathrm{O}_{2}$, differences in the settlement of zoospores and removal of sporelings were not significant relative to a titanium-free C8/TEOS xerogel. Addition of $\mathrm{H}_{2} \mathrm{O}_{2}$ gave a significant reduction in zoospore settlement and sporeling removal relative to the $\mathrm{C} 8 / \mathrm{TEOS}$ xerogel and relative to peroxide-free conditions. The impact of TTIP on xerogel characteristics was evaluated by comprehensive contact angle analysis, scanning electron microscopy, and X-ray photoelectron spectroscopy.

Key Words: marine biofouling; xerogels; Ulva linza; antifouling; hydrogen peroxide; titanium oxide 


\section{Introduction}

Marine biofouling is a continual problem for the shipping industry (Banerjee et al. 2011). Biofouling leads to an increase in roughness and drag on ships' hulls with subsequent loss of range and speed (Schultz 2007). Fuel consumption may account for up to $60 \%$ of a ship's operating costs and may increase by up to $40 \%$ in just six months on a ship without any treatment to minimize fouling (Schultz et al. 2011). Escalation in the production of greenhouse gases (through increased fuel consumption), corrosion, and the onset of cavitation also result from marine biofouling (Jack 1999; Atlar et al. 2011).

Antifouling (AF) paints containing metal complexes and/or biocides are currently used to combat marine biofouling, but raise concerns for environmental damage through leaching of metals or biocides (Borghi and Porte 2002; Chambers et al. 2006; Almeda et al. 2007). The recent development of fouling-release (FR) coatings to facilitate the removal of fouling organisms via water flow or cleaning, provides a more environmentally benign approach to reduce the effects of biofouling (Rosenhahn et al. 2010). FR technology largely relies on the use of silicone elastomers with low surface energy and modulus, properties that favor the release of fouling organisms (Baier et al. 1968; Pagliaro et al. 2009; Detty et al. 2014). The use of FR coatings to combat biofouling on immersed surfaces is limited by the fact that fouling is removed only in the presence of hydrodynamic shear or through regular cleaning (Lejars et al. 2012; Sokolova et al. 2012; Detty et al. 2014).

Coatings with the ability to generate materials in situ, either to discourage settlement or to minimize adhesion of biofouling organisms from reagents naturally present in seawater, represent one approach to combine the benefits of both AF and FR technologies (McMaster et al. 2009; Natalio et al. 2012; Ciriminna et al. 2015). The oxidation of halide salts with $\mathrm{H}_{2} \mathrm{O}_{2}$ found 
in the aquatic environment can produce hypohalous acids in situ. The hypohalous acids have known biocidal effects (Williams and Schroeder 2004; Drabkova 2007) and discourage settlement of some species when generated in situ (McMaster et al. 2009; Natalio et al. 2012). Hydrogen peroxide thermodynamically can oxidize chloride, bromide, and iodide. For chloride and bromide, these reactions are kinetically slow (Mohammad and Liebhafsky 1934).

Hydrogen peroxide is found in the open ocean at concentrations up to $0.2 \mu \mathrm{M}$ (Yuan and Shiller 2001) and can approach $50 \mu \mathrm{M}$ in ports fed by rain water (Willey et al. 1999; Yuan and Shiller 2000) or by runoff (Clark et al. 2008). Hydrogen peroxide is also formed by photochemical decomposition of organic matter near the water surface (Cooper and Zika 1983) and can be produced by bacteria in the biofilm on submerged surfaces, approaching concentrations of $50 \mu \mathrm{M}$ (Le Bozek et al. 2001). The ambient $\mathrm{H}_{2} \mathrm{O}_{2}$ can react with chloride $(0.5$ M), bromide $(\mathrm{mM})$, and iodide $(\mu \mathrm{M})$ present in seawater to produce low concentrations of hypohalous acid. The AF characteristics of a coating can be improved through the use of a coating-sequestered catalyst to activate $\mathrm{H}_{2} \mathrm{O}_{2}$ to increase the production of hypohalous acids at the surface generating a chemical deterrent for settlement of marine fouling organisms (McMaster et al. 2009; Natalio et al. 2012).

Sol-gel-derived xerogel coatings based on amorphous silica have shown promise as FR coatings (Sokolova et al. 2012; Sokolova et al. 2012a; Evariste et al. 2013) and have been modified to incorporate organochalcogenide catalysts for the activation of $\mathrm{H}_{2} \mathrm{O}_{2}$ (McMaster et al. 2009; Gatley et al. 2015). While they have shown some promise as AF coatings (McMaster et al. 2009), the FR characteristics of the surface are modified by the presence of the organochalcogen catalyst and FR characteristics may actually be reduced. Incorporating the catalytic site for activation of $\mathrm{H}_{2} \mathrm{O}_{2}$ as part of the inorganic matrix of the xerogel rather than in the organic 
modifications imparting FR properties may lead to improved AF/FR characteristics of the surfaces.

The grafting of transition metals to mesoporous silica has provided an array of catalysts for the oxidation of halide salts with $\mathrm{H}_{2} \mathrm{O}_{2}$ (Walker et al. 1997). Oxidation of chloride with titanium grafted onto mesoporous silica was observed at $\mathrm{pH} 4$ but not at $\mathrm{pH} 6.5$ or higher, while oxidation of bromide with $\mathrm{H}_{2} \mathrm{O}_{2}$ was observed over the $\mathrm{pH}$ range 4-8. Oxidation of bromide with $\mathrm{H}_{2} \mathrm{O}_{2}$ has been observed with several grafted metals on silica in the reactivity order $\mathrm{W}>\mathrm{Mo}>\mathrm{Ti}>\mathrm{Zr}>\mathrm{V}$ $>$ Re (Morey et al. 2000). Though the grafting of transition metals onto mesoporous silica does not present a practical approach to AF/FR coatings covering large surface areas, it does illustrate the potential of incorporating transition metal oxides into xerogel surfaces.

Herein, we describe the preparation of xerogel coatings via the sol-gel process that incorporate titanium tetraisopropoxide (TTIP) as part of the inorganic matrix and the AF/FR characteristics of these coatings toward zoospores and sporelings of the marine alga Ulva linza. The characterization of these surfaces by contact-angle analysis, scanning electron microscopy (SEM), and X-ray photoelectron spectroscopy (XPS) is also described. Importantly, the Ticontaining xerogels catalyze the oxidation of both chloride and bromide with $\mathrm{H}_{2} \mathrm{O}_{2}$ to produce the corresponding hypohalous acids at $\mathrm{pH} 8$, which is the $\mathrm{pH}$ of seawater.

\section{Materials and methods}

\section{Chemicals, Reagents, and Materials}

Deionized (DI) water was prepared to a specific resistivity of at least $18 \mathrm{M} \Omega$ using a Barnstead NANOpure Diamond UV ultrapure water system. Tetraethoxy orthosilicate (TEOS) and $n$ octyltriethoxysilane (C8) were purchased from Gelest, Inc. and were used as received. Ethanol was purchased from Decon Laboratories. Hydrochloric acid, 2-propanol, and 30\% hydrogen 
peroxide were obtained from Fisher Scientific Co. Titanium tetraisopropoxide (TTIP) and 4pentenoic acid were obtained from Acros Organics and were used as received. Deuterium oxide (>99\%) was obtained from Cambridge Isotopes. Borosilicate glass microscope slides were obtained from Fisher Scientific, Inc.

The artificial seawater (ASW) used in chemical analysis was prepared via modification of the Marine Biological Laboratory (Woods Hole, Massachusetts, USA) recipe [Biological Bulletin Compendia: $\quad$ http://hermes.mbl.edu/BiologicalBulletin/COMPENDIUM/CompTab3.html\#3A]. In addition to the salts used in the MBL recipe, $1.0 \mathrm{mM}$ of sodium bromide and $1.0 \mu \mathrm{M}$ of sodium iodide were added to give a more realistic representation of the halide ions present in natural seawater. For algal assays, artificial seawater (ASW) was made from Tropic Marin ${ }^{\circledR}$ salts.

\section{Xerogel composition}

Xerogel monoliths were prepared at room temperature. A TEOS monolith was prepared by mixing TEOS $(10.0 \mathrm{mmol}, 2.23 \mathrm{ml})$ and EtOH $(10.4 \mathrm{mmol}, 607 \mu \mathrm{l})$ in a glass vial while stirring. Water $(13.5 \mathrm{mmol}, 243 \mu \mathrm{l})$ and $\mathrm{HCl}(24.6 \mu \mathrm{l}$ of a $1.0 \mathrm{M}$ solution) were combined in a separate vial and added dropwise to the reaction mixture with stirring. Following addition of acid, the monolith was left stirring open to the atmosphere, at ambient temperature until gel formation was observed and all solvent had evaporated. The xerogel was then dried under reduced pressure for $48 \mathrm{~h}$ at ambient temperature, and then crushed using mortar and pestle.

The TTIP/TEOS monolith was prepared following the TEOS protocol using TTIP (2.00 mmol, $0.592 \mathrm{ml})$ and TEOS $(8.00 \mathrm{mmol}, 1.79 \mathrm{ml})$ in the initial step (20:80 molar ratio of TTIP to TEOS). The C8/TEOS monolith was prepared following the TEOS protocol using C8 (4.00 mmol, $1.26 \mathrm{ml})$ and TEOS $(6.00 \mathrm{mmol}, 1.34 \mathrm{ml}$; a 40:60 molar ratio of TTIP to TEOS). The 
TTIP/C8/TEOS monolith was prepared following the TEOS protocol using TTIP (2.00 mmol, $0.592 \mathrm{ml}), \mathrm{C} 8(4.00 \mathrm{mmol}, 1.26 \mathrm{ml})$ and TEOS $(4.00 \mathrm{mmol}, 893 \mu \mathrm{l}$; a 20:40:40 molar ratio of TTIP, C8, and TEOS).

Sols for spin coating were prepared at ambient temperature. A TEOS sol was prepared from $\mathrm{H}_{2} \mathrm{O}(8.00 \mathrm{mmol}, 144 \mu \mathrm{l})$ and acetic acid $(4.00 \mathrm{mmol}, 229 \mu \mathrm{l})$ in isopropanol $(7.96 \mathrm{~mL})$ and adding this solution dropwise to stirring TEOS $(4.46 \mathrm{~mL}, 20.0 \mathrm{mmol})$. The resulting sol was capped and stirred for $24 \mathrm{~h}$ prior to coating. The TTIP/TEOS sol was prepared following the TEOS protocol using TTIP $(4.00 \mathrm{mmol}, 1.18 \mathrm{ml})$ and TEOS $(16.0 \mathrm{mmol}, 3.57 \mathrm{ml})$. The C8/TEOS sol was prepared following the TEOS protocol using C8 (8.00 mmol, $2.53 \mathrm{ml})$ and TEOS (12.0 mmol, $2.68 \mathrm{ml})$. The TTIP/C8/TEOS sol was prepared following the TEOS protocol using TTIP (4.00 mmol, $1.18 \mathrm{ml}), \mathrm{C} 8(8.00 \mathrm{mmol}, 2.53 \mathrm{ml})$, and TEOS (8.00 mmol, $1.79 \mathrm{ml})$.

Xerogel films were formed as described by Bennett et al. (2010) by spin-casting $400 \mu 1$ of the sol precursor onto pre-cleaned $25 \mathrm{~mm} \times 75 \mathrm{~mm}$ glass microscope slides. Slides were cleaned by soaking in 'piranha solution' ( $\left(1: 430 \% \mathrm{H}_{2} \mathrm{O}_{2}\right.$ : concentrated $\left.\mathrm{H}_{2} \mathrm{SO}_{4}\right)$ for $24 \mathrm{~h}$, rinsed with copious quantities of DI water, soaked in isopropanol for at least $15 \mathrm{~min}$, and were air dried immediately prior to coating. A spin coater [Specialty Coating Systems, Inc., model P6700] was used at 100 rpm for $10 \mathrm{~s}$ to deliver the sol and at $3000 \mathrm{rpm}$ for $30 \mathrm{~s}$ to coat. All coated surfaces were dried at ambient temperature for at least seven days prior to analysis of the surface properties.

Characteristics of xerogel coatings: contact angles and surface energies pre- and postimmersion

Xerogel films were stored in air prior to measurement of static contact angles for the surface. Slides were then immersed in ASW for $24 \mathrm{~h}$ followed by $1 \mathrm{~h}$ in DI water to remove salts. The coatings were then allowed to dry under ambient conditions for $3 \mathrm{~h}$ before contact angles were 
remeasured. Static water contact angles $\left(\theta_{\mathrm{Ws}}\right)$ and static diiodomethane contact angles $\left[\theta_{(\mathrm{CH} 2 \mathrm{I} 2) \mathrm{s}}\right]$ were measured on a $15 \mu$ drop of fluid on the xerogel surface with a contact angle goniometer [ramé-hart, Model NRL 100]; both sides of the droplet profile were measured. Contact angles measured with water and diiodomethane were treated as described by Owens and Wendt (1969) to give total surface energy (Baier and Meyer 1992) as compiled in Table 1.

\section{Characteristics of xerogel coatings: scanning electron microscopy (SEM)}

Scanning electron micrographs were recorded using an Hitachi model SU-70 field emissionSEM with a zirconium oxide/tungsten Schottky electron emission source operating at $5 \mathrm{kV}$ acceleration voltage, three state electromagnetic lens system, octapole electromagnetic type stigmator coil, two-state electromagnetic deflection type scanning coil, Everhart Thornly secondary electron detectors, and SEM Data Manager software 1.0.

\section{Characteristics of xerogel coatings: X-ray photoelectron spectroscopy pre- and post-immersion}

The xerogel coatings were also examined by X-ray photoelectron spectroscopy (XPS), pre- and post-immersion in DI water or $200 \mu \mathrm{M} \mathrm{H}_{2} \mathrm{O}_{2}$ (Tang et al. 2005; McMaster et al. 2009; Gatley et al. 2015) using a Physical Electronics Laboratories (PHI) Model 500 VersaProbe equipped with an Aluminum X-Ray source, a hemispherical analyzer and a 16 channel detector. A monochromatic $\mathrm{Al} \mathrm{k}^{2}$ source $(1486.6 \mathrm{eV})$ was operated at $100 \mu \mathrm{m} 25 \mathrm{~W} 15 \mathrm{kV}$ with a $45^{\circ}$ takeoff angle at a pressure not exceeding $5 \times 10^{-6} \mathrm{~Pa}$ in the main chamber. Pass energies of 117.4 $\mathrm{eV}$ and $25.30 \mathrm{eV}$ were used to obtain survey and high-resolution multiregion scans, respectively. Curve fitting was performed with PHI MultiPak ${ }^{\mathrm{TM}}$ Software Version 8.

A coated slide was cut into $1 \mathrm{~cm} \times 1 \mathrm{~cm}$ samples using a diamond-tipped glass cutter. Initial analysis of the coating was performed on a dry sample that had been stored open to air. After dry analysis, the same sample was submersed for $24 \mathrm{~h}$ in DI water or in DI water with $200 \mu \mathrm{M}$ 
$\mathrm{H}_{2} \mathrm{O}_{2}$. Following the soaking procedure, the sample was rinsed in DI water and air-dried at ambient conditions for $15 \mathrm{~h}$ to ensure all water had evaporated off the coating prior to introduction to the high vacuum chamber of the instrument. While the air-drying step of the pretreatment may reverse changes to the coating caused by immersion, a dry coating is required for the high vacuum conditions of XPS. The composition of the surface, which is dry but previously immersed, corresponds to a kinetically trapped condition rather than the thermodynamic equilibrium state when in contact with water, as the recovery from immersion is slow for xerogel films (Martinelli et al. 2008; Evariste et al. 2013).

\section{Kinetic Studies of halogenation reactions with xerogel monoliths}

The halogenation of 4-pentenoic acid was monitored by ${ }^{1} \mathrm{H}$ NMR spectroscopy using previously described techniques (Alberto et al. 2015; Gatley et al. 2015). Briefly, a stock solution of pH 7.0 buffer was prepared from a $0.72: 1$ molar ratio of $\mathrm{K}_{2} \mathrm{HPO}_{4} / \mathrm{KH}_{2} \mathrm{PO}_{4}(0.23 \mathrm{M}$ in total phosphate $)$ was prepared in $\mathrm{D}_{2} \mathrm{O}$ with propionic acid $(0.01 \mathrm{M})$ as an internal standard. A pH 8.0 buffer was prepared from a $0.14: 1$ molar ratio of $\mathrm{K}_{2} \mathrm{HPO}_{4} / \mathrm{KH}_{2} \mathrm{PO}_{4}(0.23 \mathrm{M}$ in total phosphate) with final $\mathrm{pH}$ adjusted using $3 \mathrm{M} \mathrm{NaOH}$. For brominations, $\mathrm{NaBr}$ ( $7.5 \mathrm{mmol}, 1.4 \mathrm{M}$ final concentration), and 4-pentenoic acid (1, $0.075 \mathrm{~g}, 0.75 \mathrm{mmol}, 0.14 \mathrm{M}$ final concentration), were added to $5.0 \mathrm{~mL}$ of the stock solution of $\mathrm{pH} 7.0$ buffer followed by the xerogel monolith $[8.7 \mathrm{mg}$ of either the TTIP/TEOS monolith $(0.027 \mathrm{mmol} \mathrm{Ti}, 0.035$ equiv based on total Ti relative to substrate) or the TEOS monolith or $11.5 \mathrm{mg}$ of the TTIP/C $8 /$ TEOS $(0.027 \mathrm{mmol} \mathrm{Ti}, 0.035$ equiv based on total Ti relative to substrate), TEOS, or the $\mathrm{C} 8$ /TEOS monolith]. The $\mathrm{H}_{2} \mathrm{O}_{2}(0.26 \mathrm{~mL}$ of a $4.4 \mathrm{M}$ aqueous solution, $1.1 \mathrm{mmol}, 0.21 \mathrm{M}$ final concentration) was added and the reaction vessels were placed in a thermostat-controlled bath at $298 \pm 1 \mathrm{~K}$. 
For chlorinations, the process was repeated with $\mathrm{NaCl}$ ( $15 \mathrm{mmol}, 2.7 \mathrm{M}$ final concentration), 4-pentenoic acid $(1,0.075 \mathrm{~g}, 0.75 \mathrm{mmol}, 0.14 \mathrm{M})$, and $5.0 \mathrm{~mL}$ of the stock solution of $\mathrm{pH} 7.0$ $\mathrm{KH}_{2} \mathrm{PO}_{4}$ or $\mathrm{pH} 8.0$ buffer. The xerogel monolith $[0.15 \mathrm{~g}$ of the TTIP/TEOS monolith $(0.45 \mathrm{mmol}$ Ti) or the TEOS monolith or $0.23 \mathrm{~g}$ of the TTIP/C8/TEOS $(0.45 \mathrm{mmol} \mathrm{Ti})$, TEOS, or the C8/TEOS monolith] was added followed by $\mathrm{H}_{2} \mathrm{O}_{2}(0.43 \mathrm{~mL}$ of an $8.8 \mathrm{M}$ solution, $3.8 \mathrm{mmol}, 0.68$ M). The reaction vessels were placed in a thermostat-controlled bath at $298 \pm 1 \mathrm{~K}$.

Reaction mixtures were periodically sampled by ${ }^{1} \mathrm{H}$ NMR spectroscopy with suppression of $\mathrm{H}_{2} \mathrm{O}$ and DOH signals. Consumption of 4-pentenoic acid was determined from the relative integral values of the internal alkene proton of 4-pentenoic acid $(\delta=5.8 \mathrm{ppm})$ and the methylene protons of propionic acid $(\delta=1.1 \mathrm{ppm})$. The experiments were followed through the one to three half-lives and results plotted assuming pseudo-first order conditions [n [4-pentenoic acid] vs. time (s)]. NMR spectra were recorded on an Inova $500\left(500 \mathrm{MHz}\right.$ for $\left.{ }^{1} \mathrm{H}\right)$ or Inova 300 instrument (300 MHz for $\left.{ }^{1} \mathrm{H}\right)$.

Bromination of 4-pentenoic acid (1) gave 5-(bromomethyl)dihydrofuran-2(3H)-one (3a, Scheme 1) with spectral characteristics matching those previously reported (Alberto et al. 2015, Gatley et al. 2015). Chlorination of 1 gave 5-(chloromethyl)dihydrofuran-2(3H)-one (3b, Scheme 1) with spectral characteristics matching those previously reported (Genovese et al. 2010).

\section{Kinetic studies of halogenation reactions on xerogel-coated glass cuvettes}

A $1 \mathrm{~cm} \times 1 \mathrm{~cm}$ glass cuvette was cleaned by soaking in 'piranha solution' $\left(1: 430 \% \mathrm{H}_{2} \mathrm{O}_{2}\right.$ : concentrated $\mathrm{H}_{2} \mathrm{SO}_{4}$ ) for $24 \mathrm{~h}$, rinsing with copious quantities of DI water, soaking in isopropanol for $3 \mathrm{~h}$, and drying in air. A xerogel film was then applied to one side of the cuvette 
by administering $1.0 \mathrm{ml}$ of the 20:40:40 TTIP:C8:TEOS sol for $60 \mathrm{~s}$, after which the remaining sol was removed. The 'coated cuvette' was dried at ambient temperature for 5 days prior to use.

The halogenation of phenol red was monitored by UV-Vis spectroscopy in the coated cuvette. Phenol red $(0.15 \mu \mathrm{mol}, 50 \mu \mathrm{M}$ final concentration $)$ and $\mathrm{H}_{2} \mathrm{O}_{2}(0.15 \mu \mathrm{mol}, 50 \mu \mathrm{M}$ final concentration) were added to $2.8 \mathrm{ml}$ of artificial seawater $(0.5 \mathrm{M}$ in chloride, $1.0 \mathrm{mM}$ in bromide, and $1.0 \mu \mathrm{M}$ in iodide at $\mathrm{pH}$ 8) in the coated cuvette. Halogenation of phenol red was monitored over a $24-\mathrm{h}$ period at $298 \pm 1 \mathrm{~K}$. The chlorination of phenol red was followed via the incremental addition of chlorine bleach $(\mathrm{HOCl})$ to give the equivalent of $10,15,25,50,75,100$, and $200 \mu \mathrm{M}$ HOCl.

\section{Biological Assays}

\section{Settlement of zoospores of Ulva linza}

Fronds of $U$. linza were collected from Craster, Northumberland, UK $\left(55^{\circ} 26^{\prime} \mathrm{N} ; 1^{\circ} 35^{\prime} \mathrm{W}\right)$ and a spore suspension of $1.0 \times 10^{6}$ spores $\mathrm{mL}^{-1}$ was prepared by the method of Callow et al. (1997). The experiment used 3 replicates of each coating for each treatment. All coatings were equilibrated in $0.22 \mu \mathrm{m}$-filtered ASW with added $\mathrm{H}_{2} \mathrm{O}_{2}(0,50,100$ and $150 \mu \mathrm{M})$, depending on the treatment, for $24 \mathrm{~h}$ prior to testing. A suspension of zoospores $\left(10 \mathrm{~mL} ; 1 \times 10^{6}\right.$ spores $\left.\mathrm{mL}^{-1}\right)$ was added to individual compartments of quadriPERM ${ }^{\circledR}$ dishes containing the samples. After 45 min in darkness at $20^{\circ} \mathrm{C}$, the slides were washed by passing $10 \times$ through a beaker of seawater to remove unsettled (i.e. swimming) spores. Slides were fixed using $2.5 \%$ glutaraldehyde in seawater. The density of zoospores attached to the surface was counted on each of 3 replicate slides using an image analysis system attached to a Zeiss Axioscope 2 plus fluorescence microscope. Spores were visualized by autofluorescence of chlorophyll. Counts were made using Axiovision 4 software for 30 fields of view $\left(0.15 \mathrm{~mm}^{2}\right)$ on each slide. 


\section{Settlement of zoospores of $\mathrm{U}$. linza in the presence of sodium hypochlorite}

Reagent grade sodium hypochlorite solution was purchased from Sigma: (Sigma 425044250ML-D). The solution contained available chlorine at 10-15\%. Molar concentrations were calculated on the basis of $12.5 \%$ chlorine. The sodium hypochlorite solution was diluted in ASW to produce a range of dilutions in 24-well plates, to which spores were added (suspension of $3.33 \times 10^{5}$ spore $\mathrm{ml}^{-1}$ ). After $45 \mathrm{~min}$ in darkness at c. $20^{\circ} \mathrm{C}$, the wells were washed to remove unsettled (i.e. swimming) spores by emptying and refilling with filtered ASW twice. Wells were fixed using $2.5 \%$ glutaraldehyde in seawater and the density of zoospores attached to the surface was counted on each of 4 replicate wells using the image analysis system as described above. Spores were visualized by autofluorescence of chlorophyll. Counts were made using Axiovision 4 software for 10 fields of view $\left(0.15 \mathrm{~mm}^{2}\right)$ on each slide. $\mathrm{EC}_{50}$ values were determined by graphical interpolation.

\section{Growth and attachment of sporelings of $\mathrm{U}$. linza}

Spores were allowed to settle on 6 coated slides for $45 \mathrm{~min}$ and then washed as described above. Spores were cultured using enriched seawater medium (Starr and Zeikus 1987) for 7 days to produce sporelings (young plants). Sporeling growth medium was refreshed every $48 \mathrm{~h}$ along with $\mathrm{H}_{2} \mathrm{O}_{2}$ as appropriate. Sporeling biomass was determined in situ by measuring the fluorescence of the chlorophyll contained within the sporelings in a Tecan fluorescence plate reader. The relative fluorescence unit (RFU) value for each slide was derived from the mean of 70 point fluorescence readings taken from the central portion of each slide. The strength of attachment of sporelings was assessed using an impact pressure of $30 \mathrm{kPa}$ from a water jet (Aldred et al. 2010). Biomass remaining was determined using the fluorescence plate reader (as 
above). Percentage removal was calculated from readings taken before and after exposure to the water jet.

\section{Growth of sporelings of $\mathrm{U}$. linza in the presence of sodium hypochlorite}

The sodium hypochlorite solution was diluted in seawater (nutrient supplemented) to produce a range of dilutions in 24-well plates, to which spores were added (suspension of $3.33 \times 10^{5}$ spore

$\mathrm{ml}^{-1}$ ). Four replicate wells of each concentration were prepared. The plates were incubated for 7 d in an illuminated chamber at $18{ }^{\circ} \mathrm{C}$. Biomass was quantified as chlorophyll, which was extracted in dimethyl sulfoxide (DMSO). Plates were then incubated in darkness for $1 \mathrm{~h}$ to ensure the chlorophyll in the sporelings had been extracted. The fluorescence of the samples was read in a Tecan fluorescence plate reader. $\mathrm{EC}_{50}$ values were determined by graphical interpolation.

\section{Data analysis and statistics}

For biological assays on coated slides, statistical significance was assessed using one-way ANOVA and a post-hoc multiple pairwise comparison using the Tukey test with a significance level of 0.05. The Student's t-test was used for pair-wise comparisons of independent samples with respect to physicochemical characteristics of surfaces with one nominal variable and one measurement variable. A $p$ value $<0.05$ was considered significant.

\section{Results}

\section{Characterization of surfaces: appearance and optical transparency}

TEOS, TTIP/TEOS, C8/TEOS and TTIP/C8/TEOS sols were cast via spin-coating onto glass slides to give colorless, transparent coatings. Sols can also be applied to larger surfaces via dipcoating or brushing. Surfaces are uniform in appearance via all modes of coating. 


\section{Characterization of surfaces: contact angles and surface energies}

Static water contact angles, $\theta_{\mathrm{Ws}}{ }^{\circ}$ and static diiodomethane contact angles, $\theta_{(\mathrm{CH} 2 \mathrm{I2}) \mathrm{s}}{ }^{\circ}$ (Table 1) were measured for all xerogel surfaces described in this study pre- and post-immersion in ASW. Contact angles measured with water and diiodomethane were treated as described by Owens and Wendt (1969) to give total surface energy $\left(\gamma_{\mathrm{S}}\right)$ (Baier and Meyer 1992) for the xerogel surfaces of this study pre- and post-immersion in ASW (Table 1).

Prior to immersion, the TEOS and the TTIP/TEOS xerogel coatings had comparable values of $\theta_{\mathrm{Ws}}{ }^{\circ},\left(44^{\circ}\right.$ and $45^{\circ}$, respectively, Table 1) and $\gamma_{\mathrm{S}}\left(56\right.$ and $57 \mathrm{mN} \mathrm{m}^{-1}$, respectively) that were not significantly different to each other $(p=0.72$ and $p=0.57$, respectively). Post immersion, values of $\theta_{\mathrm{Ws}_{\mathrm{s}}}{ }^{\circ}\left(31^{\circ}\right.$ and $35^{\circ}$, respectively) decreased significantly $(p<0.0001$ and $p=0.0015$, respectively) and values of $\gamma_{\mathrm{S}}$ (63.9 and $62.1 \mathrm{mN} \mathrm{m}^{-1}$, respectively) increased significantly ( $p=$ 0.0028 and $p=0.038$, respectively) from pre-immersion values. However, comparing these values for both surfaces post immersion indicated that differences between the two surfaces were not significant ( $p=0.17$ for $\theta_{\mathrm{Ws}}{ }^{\circ}$ and $p=0.19$ for $\left.\gamma_{\mathrm{S}}\right)$.

The C8/TEOS xerogel coating and the TTIP/C8/TEOS xerogel coating had comparable values of $\theta_{\mathrm{Ws}}{ }^{\circ}\left(102.8^{\circ}\right.$ and $99.1^{\circ}$, respectively) and $\gamma_{\mathrm{S}}\left(23.2\right.$ and $25.0 \mathrm{mN} \mathrm{m}^{-1}$, respectively) preimmersion in ASW (Table 1). These differences in $\gamma_{\mathrm{S}}$, though small, were significant (Student's t-test, $p=0.0002)$ Following immersion, values of $\theta_{\mathrm{Ws}}{ }^{\circ}\left(99.4^{\circ}\right.$ and $94.1^{\circ}$ for the C8/TEOS and the TTIP/C8/TEOS xerogels, respectively) decreased significantly $(p<0.0001$ and $p=0.0003$, respectively) and values of $\gamma_{\mathrm{S}}$ (26 and $27 \mathrm{mN} \mathrm{m}^{-1}$, respectively) increased significantly ( $p=$ 0.0089 and $p=0.026$, respectively) from pre-immersion values (Table 1). Post immersion, values of $\gamma_{S}$ were not significantly different $(p=0.29)$ for the two surfaces.

\section{Characterization of surfaces: scanning electron microscopy (SEM)}


Figure 1 depicts typical SEM images for the TTIP/C8/TEOS xerogel viewed from the top and along an edge pre- and post-immersion in ASW. Pre-immersion images were obtained from xerogel surfaces stored in air for one week following coating. Post-immersion images were obtained from xerogel surfaces immersed in ASW for $7 \mathrm{~d}$ followed by a rinse with DI water. The xerogel surfaces are smooth and uncracked both pre- and post-immersion. The view along the edge shows that the surfaces are approximately $0.5 \mu \mathrm{m}$ thick.

\section{Characterization of surfaces: $X$-ray photoelectron spectroscopy (XPS)}

XPS spectra of the TTIP/C8/TEOS xerogel surfaces were recorded at a take-off angle of $45^{\circ}$ to determine atomic composition at the surface of the xerogel coating pre- and post-immersion for $24 \mathrm{~h}$ in DI water or for $24 \mathrm{~h}$ in $200 \mu \mathrm{M} \mathrm{H}_{2} \mathrm{O}_{2}$. Results are shown in Figure 2 as elemental ratios for the $\mathrm{C}(1 \mathrm{~s}) / \mathrm{Si}(2 \mathrm{p} 3), \mathrm{C}(1 \mathrm{~s}) / \operatorname{Ti}(2 \mathrm{p})$, and $\mathrm{Si}(2 \mathrm{p} 3) / \mathrm{Ti}(2 \mathrm{p})$ signals as determined by area under the peaks corrected for relative sensitivity factors. In clean borosilicate glass, the ratio of the $\mathrm{C}(1 \mathrm{~s}) / \mathrm{Si}(2 \mathrm{p} 3)$ signals is $0.28 \pm 0.02$, which is quite similar to the ratio of 0.2 reported by Tang et al. (2005), suggesting a relatively carbon-free surface with any carbon found presumably arising from adventitious/adsorbed carbon-containing species from the atmosphere.

The elemental ratios shown in Figure 2 are not significantly different pre- and postimmersion in either DI water or $200 \mu \mathrm{M} \mathrm{H}_{2} \mathrm{O}_{2}$ (Student's t-test, $p>0.05$ ). These data suggest that neither immersion in water nor exposure to aqueous peroxide results in significant changes to the surface structure with respect to $\mathrm{C}, \mathrm{Si}$, and $\mathrm{Ti}$.

\section{Oxidation of bromide with $\mathrm{H}_{2} \mathrm{O}_{2}$ catalyzed by xerogel monoliths}

For the TTIP/TEOS and TTIP/C8/TEOS xerogel coatings to have active AF characteristics, the coatings should oxidize halide salts in the presence of $\mathrm{H}_{2} \mathrm{O}_{2}$. The 20:80 TTIP/TEOS and 20:40:40 TTIP/C8/TEOS monoliths were prepared and ground into a fine powder using a mortar 
and pestle. For comparison, Ti-free TEOS-only and C8/TEOS monoliths were prepared and were similarly ground into a fine powder. The ability of these four monoliths to catalyze the halogenation of 4-pentenoic acid (1) to give 4,5-dihalopentanoic acids 2 and/or 5(halomethyl)dihydrofuran-2(3H)-ones 3 (Scheme 1) with $\mathrm{H}_{2} \mathrm{O}_{2}$ and either $\mathrm{NaBr}$ or $\mathrm{NaCl}$ was examined. 4-Pentenoic acid has been used as a reporter molecule in several studies because of its very rapid reaction with hypohalous acids (Goodman \& Detty 2004, Bennett et al. 2008, Alberto et al. 2015, Gatley et al. 2015).

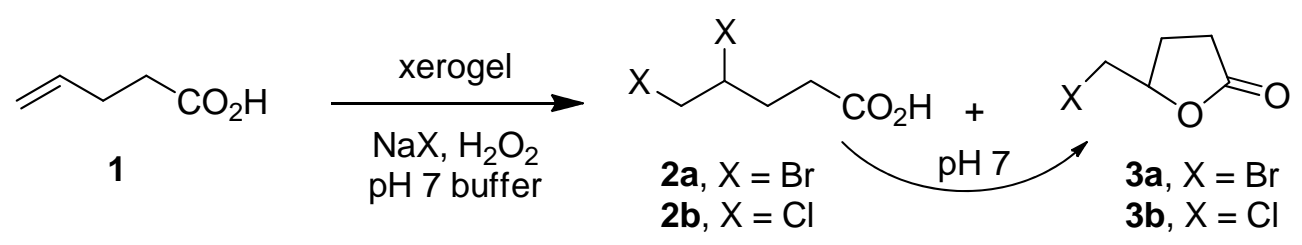

Scheme 1. Halogenation of 4-pentenoic acid (1) with hypobromous or hypochlorous acid.

Bromination of 1 at $\mathrm{pH} 7$ and $298 \pm 1 \mathrm{~K}$ with $1.4 \mathrm{M} \mathrm{NaBr}$ and $0.21 \mathrm{M} \mathrm{H}_{2} \mathrm{O}_{2}$ with the TTIP/TEOS or TTIP/C8/TEOS monoliths (3.5 mole-\% Ti relative to 1 ) or an equivalent weight of the TEOS or C8/TEOS monoliths was followed by ${ }^{1} \mathrm{H}$ NMR spectroscopy. The loss of 1 was followed as well as the appearance of a mixture of 4,5-dibromopentanoic acid (2a) and bromolactone 3a. The ${ }^{1} \mathrm{H}$ NMR chemical shifts of the olefinic protons of $\mathbf{1}$ are distinct from the bromomethine proton of $\mathbf{2 a}$ and the lactone methine proton of 3a. At $\mathrm{pH} 7$ or higher, 2a is converted to 3a upon standing. Rate constants, $k_{\mathrm{obs}}$, for loss (or bromination) of $\mathbf{1}$ are compiled in Table 2. As shown in Figure 3a for the TEOS-only, TTIP/TEOS, and TTIP/C8/TEOS xerogels, pseudo-first-order behavior was observed for the loss of $\mathbf{1}$ with concomitant formation of $\mathbf{2 a}$ and 3a. Bromination with the TTIP/TEOS xerogel $\left[k_{\mathrm{obs}},=(8.44 \pm 0.10) \times 10^{-5} \mathrm{~s}^{-1}\right]$ was 340 -fold faster than bromination with the Ti-free, TEOS-only xerogel $\left[k_{\text {obs }}\right.$ of $\left.(2.47 \pm 0.15) \times 10^{-7}\right]$ while 
bromination with the TTIP/C $8 /$ TEOS xerogel $\left[k_{\mathrm{obs}}=(3.37 \pm 0.09) \times 10^{-6} \mathrm{~s}^{-1}\right]$ was 14 -fold faster (Table 2).

As shown in Figure 4b, TTIP/C8/TEOS catalyzed the oxidation of bromide with $\mathrm{H}_{2} \mathrm{O}_{2}$ at $\mathrm{pH}$ 8. The rate was 2 -fold faster at $\mathrm{pH} 8$ than the control reaction with the TEOS monolith as catalyst (Table 3).

\section{Oxidation of chloride with $\mathrm{H}_{2} \mathrm{O}_{2}$ catalyzed by xerogel monoliths}

Oxidation of chloride was slower at $298 \pm 1 \mathrm{~K}$ and utilized higher concentrations of halide (2.7 $\mathrm{M} \mathrm{NaCl})$ and $\mathrm{H}_{2} \mathrm{O}_{2}(0.68 \mathrm{M})$ and a 60 mole- $\%$ in Ti loading of the TTIP/TEOS and TTIP/C8/TEOS xerogels. As shown in Figure 3c, pseudo-first-order behavior was observed for the loss of $\mathbf{1}$ with concomitant formation of $\mathbf{2} \mathbf{b}$ and $\mathbf{3} \mathbf{b}$ in the presence of TEOS-only, TTIP/TEOS, and TTIP/C8/TEOS xerogels. Chlorination with the TTIP/TEOS xerogel $\left[k_{\mathrm{obs}},=\right.$ $\left.(1.51 \pm 0.05) \times 10^{-5} \mathrm{~s}^{-1}\right]$ was 100 -fold faster than chlorination with the Ti-free, TEOS-only xerogel $\left[k_{\text {obs }}\right.$ of $\left.(1.89 \pm 0.68) \times 10^{-7}\right]$ while chlorination with the TTIP/C $8 /$ TEOS xerogel $\left[k_{\text {obs }}=\right.$ $\left.(3.37 \pm 0.09) \times 10^{-6} \mathrm{~s}^{-1}\right]$ was 22 -fold faster (Table 2). An intermediate level of the TTIP/C8/TEOS monolith (20 mole-\% Ti relative to 1 ) gave $k_{\text {obs }}$ for chlorination of 1 of (1.03 \pm $0.05) \times 10^{-6} \mathrm{~s}^{-1}($ Table 2$)$.

As shown in Figure 3d, the TTIP/C8/TEOS xerogel catalyzed the chlorination of 1 with $\mathrm{NaCl}$ $(2.7 \mathrm{M})$ and $\mathrm{H}_{2} \mathrm{O}_{2}(0.68 \mathrm{M})$ at $\mathrm{pH}$ 8.0. The Ti-containing xerogel gave a 20 -fold increase in rate relative to the Ti-free TEOS xerogel.

\section{Oxidation of halide salts with $\mathrm{H}_{2} \mathrm{O}_{2}$ in $\mathrm{ASW}$}

The halogenation of 4-pentenoic acid (1) at $298 \pm 1 \mathrm{~K}$ in ASW (pH 8) containing $0.5 \mathrm{M}$ chloride, $1.0 \mathrm{mM}$ bromide, $1.0 \mu \mathrm{M}$ iodide and $50 \mu \mathrm{M} \mathrm{H} \mathrm{H}_{2} \mathrm{O}_{2}$ was monitored by ${ }^{1} \mathrm{H}$ NMR spectroscopy. The reaction vessel was a glass cuvette coated on one internal face with the 
TTIP/C8/TEOS xerogel. After 5 days, no loss of 1 was observed and no halogenation products of 1 were detected.

The halogenation of phenol red, which has been used to monitor the oxidation of halide salts with $\mathrm{H}_{2} \mathrm{O}_{2}$ (Walker et al. 1997), was also examined. Incremental addition of bleach (HOCl) to give the equivalent of $10,15,25,50,75,100$, and $200 \mu \mathrm{M} \mathrm{HOCl}$ to phenol red $(50 \mu \mathrm{M})$ at $298 \pm$ $1 \mathrm{~K}$ in ASW ( $\mathrm{pH}$ 8) was monitored spectrophotometrically as shown in Figure 4a. An expansion of the 400-450-nm region is shown in Figure $4 \mathrm{~b}$ for $0,10,15$, and $25 \mu \mathrm{M} \mathrm{HOCl}$. The halogenation of phenol red $(50 \mu \mathrm{M})$ at $298 \pm 1 \mathrm{~K}$ in ASW (pH 8) containing $50 \mu \mathrm{M} \mathrm{H}_{2} \mathrm{O}_{2}$ was monitored spectrophotometrically in the glass cuvette coated on one internal face with the TTIP/C8/TEOS xerogel. After $24 \mathrm{~h}$, minimal halogenation of phenol red was observed (Figures $4 b$ and $4 c)$.

\section{Settlement of zoospores of $\mathrm{U}$. linza}

The 50:50 C8/TEOS xerogel, used as a control xerogel surface in previous studies (Bennett et al. 2010; Gunari et al. 2011; Sokolova et al. 2012; Sokolova et al. 2012a), and the 20:40:40 TTIP/C8/TEOS xerogel were soaked in either ASW, or in ASW with different concentrations of $\mathrm{H}_{2} \mathrm{O}_{2}$ for $24 \mathrm{~h}$ prior to settlement of zoospores of $U$. linza. Spore settlement data on these surfaces are shown in Figure 5. One-way analysis of variance indicated that there were significant differences within the data set $\left(\mathrm{F}_{5,534}=157 \mathrm{P}<0.001\right)$. A post-hoc Tukey test showed there was no significant difference in spore settlement between the control 50:50 C8/TEOS xerogel surface and the 20/40/40 TTIP/C8/TEOS xerogel surface in the absence of $\mathrm{H}_{2} \mathrm{O}_{2}(p=0.073)$. However, at 50 and $100 \mu \mathrm{M} \mathrm{H} \mathrm{H}_{2} \mathrm{O}_{2}$, spore settlement densities on the TTIP/C8/TEOS xerogel surface were significantly reduced relative to the C8/TEOS surface. The addition of $50 \mu \mathrm{M} \mathrm{H}_{2} \mathrm{O}_{2}$ gave an $11 \%$ decrease in mean settlement on the $\mathrm{C} 8$ /TEOS coating, but 
a 53\% decrease in mean settlement on the TTIP/C $8 /$ TEOS coating $(p<0.001)$. The addition of $100 \mu \mathrm{M} \mathrm{H}_{2} \mathrm{O}_{2}$ gave a $17 \%$ decrease in settlement on the C8/TEOS coating and a $56 \%$ decrease in settlement on the TTIP/C8/TEOS coating $(p<0.001)$.

\section{Growth and attachment of sporelings of $\mathrm{U}$. linza}

Sporelings grew well on all surfaces in ASW and in ASW supplemented with $50 \mu \mathrm{M}$ and 100 $\mu \mathrm{M} \mathrm{H}_{2} \mathrm{O}_{2}$. A green covering was visible on all surfaces after seven days. One-way analysis of variance $\left(\mathrm{F}_{5,30}=12.2 \mathrm{P}<0.001\right)$ and Tukey test showed that, there was no significant difference in sporeling biomass on the C8/TEOS and TTIP/C8/TEOS coatings in the absence of $\mathrm{H}_{2} \mathrm{O}_{2}(p=$ 0.99 , Figure $6 \mathrm{a}$ ). The addition of $50 \mu \mathrm{M} \mathrm{H}_{2} \mathrm{O}_{2}$ had no significant impact on sporeling biomass on the C8/TEOS control $(p=0.95)$. However, the addition of $50 \mu \mathrm{M} \mathrm{H} \mathrm{H}_{2} \mathrm{O}_{2}$ caused significant removal of sporeling biomass on the TTIP/C8/TEOS xerogel compared to the C8/TEOS xerogel ( $p=0.04)$. The presence of $100 \mu \mathrm{M} \mathrm{H}_{2} \mathrm{O}_{2}$ caused a further decrease in sporeling biomass on both control and TTIP surfaces, but the final quantities were not significantly different from each other $(p=0.11)$.

The strength of attachment of 7-day-old sporelings was assessed using an impact pressure of $30 \mathrm{kPa}$ from a water jet (Figure 6b). One-way analysis of variance $\mathrm{F}_{5,30}=6.7 \mathrm{P}<0.001$ and Tukey test showed there was no significant difference in the percentage of sporeling biomass removed from the C8/TEOS control and TTIP/C8/TEOS xerogel in the absence of $\mathrm{H}_{2} \mathrm{O}_{2}(p=$ 1.00) However, the addition of $50 \mu \mathrm{M} \mathrm{H}_{2} \mathrm{O}_{2}$ caused a significant increase in the removal of sporeling biomass from the TTIP/C8/TEOS xerogel (50.2\%) than from the C8/TEOS control coating $(23.9 \%, p=0.0011)$. With $100 \mu \mathrm{M} \mathrm{H}_{2} \mathrm{O}_{2}$, there was an increase in removal from the C8/TEOS coating resulting in no significant difference between it and TTIP/C8/TEOS xerogel ( $p$ $=0.99$ ), which suggested that $\mathrm{H}_{2} \mathrm{O}_{2}$ alone was impacting the strength of adhesion. 


\section{Settlement of zoospores of $\mathrm{U}$. linza in the presence of sodium hypochlorite}

Zoospores of $U$. linza were added to sodium hypochlorite diluted in seawater to produce a range of concentrations in 24-well polystyrene plates. Spore settlement data on polystyrene at each concentration are shown in Figure 7a. An $\mathrm{EC}_{50}$ value for 50\% inhibition of zoospore settlement was observed at $\approx 150 \mu \mathrm{M}$ sodium hypochlorite.

\section{Growth of sporelings of $\mathrm{U}$. linza in the presence of sodium hypochlorite}

Zoospores of $U$. linza were added to sodium hypochlorite diluted in seawater to produce a range of concentrations in 24-well polystyrene plates. The plates were incubated for $7 \mathrm{~d}$ and sporeling biomass was quantified as chlorophyll as shown in Figure $7 \mathrm{~b}$. A concentration of $\approx 200 \mu \mathrm{M}$ sodium hypochlorite in seawater inhibited sporeling growth by $50 \%$.

\section{Discussion}

Sol-gel processed, xerogel materials are readily prepared by the hydrolysis of metal or semimetal alkoxides to give surfaces with tunable characteristics, such as surface functionality, surface area, surface wettability, and surface energy (Brinker \& Scherer, 1990; Avnir, 1995; Dave et al. 1995; Ingersoll \& Bright, 1997). The xerogels of this study incorporate mixed titanium and silicon oxides in order to introduce titanium oxide as a catalyst for the activation of $\mathrm{H}_{2} \mathrm{O}_{2}$ in the inorganic matrix of the xerogel coating. Both the inorganic TTIP/TEOS and organically-modified TTIP/C8/TEOS xerogels, when used as crushed monoliths, accelerated the production of hypohalous acids from either sodium bromide or sodium chloride with $\mathrm{H}_{2} \mathrm{O}_{2}$ (Table 2 and Figure 3), as measured by the halogenation of 4-pentenoic acid (1, Scheme 1), and have the potential to be active AF surfaces. Oxidation of chloride with $\mathrm{H}_{2} \mathrm{O}_{2}$ via a xerogelsequestered catalyst has not been previously observed. Oxidation of chloride with $\mathrm{H}_{2} \mathrm{O}_{2}$ has 
been observed with transition metals grafted onto mesoporous silica, but these reactions failed at pH 6.5 or higher (Walker et al. 1997). Oxidation of chloride with $\mathrm{H}_{2} \mathrm{O}_{2}$ was observed with the TTIP/C8/TEOS xerogel at $\mathrm{pH} 7.0$ and at $\mathrm{pH} 8.0$.

The FR characteristics of xerogel coatings have been improved previously by incorporation of organically-modified trialkoxysilanes into the xerogel framework (Sokolova et al. 2012; Sokolova et al. 2012a; Evariste et al. 2013; Detty et al. 2014). The 50:50 C8/TEOS xerogel has shown FR characteristics with juvenile barnacles, algal sporelings, and microalgae (Tang et al. 2005; Sokolova et al. 2012). The performance of FR coatings is influenced by the inherent surface energy $\left(\gamma_{\mathrm{s}}\right)$ of the coating. For biofouling applications, $\gamma_{\mathrm{S}}$ describes the mechanical work necessary to overcome an organism's adhesion to the surface. In doing so, a new surface is created, and $\gamma_{\mathrm{S}}$ defines the energy required to create a new unit area of surface $\left(\mathrm{mN} \mathrm{m}^{-1}\right)$. The incorporation of $\mathrm{C} 8$ into the xerogel formulations lowers $\gamma_{\mathrm{s}}$ for the coating.

Replacing TEOS in the xerogel formulations with 20 mole-\% TTIP actually has minimal impact on relative values of $\gamma_{\mathrm{S}}$ in comparisons of the TEOS-only and TTIP/TEOS or C8/TEOS and TTIP/C8/TEOS coatings. For the TEOS-only and TTIP/TEOS coatings, replacing TEOS with 20 mole- $\%$ TTIP in the xerogel formulation gave no statistically significant difference between the two surfaces with respect to $\gamma_{S}$ before and after immersion in ASW (Table 1). Preimmersion in ASW, replacing TEOS in the C8/TEOS coating with 20 mole- $\%$ TTIP in the TTIP/C8/TEOS coating gave a small but significant increase in $\gamma_{\mathrm{S}}\left(23.2 \pm 0.2 \mathrm{mN} \mathrm{m}^{-1}\right.$ and $25.0 \pm$ $0.1 \mathrm{mN} \mathrm{m}^{-1}$, respectively). However, following immersion in ASW, replacing TEOS with 20 mole-\% TTIP had no significant impact on $\gamma_{\mathrm{S}}\left(26 \pm 1 \mathrm{mN} \mathrm{m}^{-1}\right.$ and $27 \pm 1 \mathrm{mN} \mathrm{m}^{-1}$, respectively, Table 1). 
The TTIP/C8/TEOS coating is colorless and transparent while the scanning electron micrographs of Figure 2 show that the surface is smooth and uncracked - even after 7 days of immersion in ASW. The SEM images of this surface appear quite similar to those reported for the 50:50 C8/TEOS surface (Tang et al. 2005) and again indicate that the substitution of TTIP for TEOS in the xerogel formulations has minimal impact on surface characteristics.

The AF characteristics of the xerogel surface can be improved by replacing TEOS in the xerogel formulation with 20 mole- $\%$ TTIP. In the absence of $\mathrm{H}_{2} \mathrm{O}_{2}$, no significant difference was observed in the settlement of zoospores of $U$. linza on the C8/TEOS xerogel control or on the TTIP/C8/TEOS xerogel surface (Figure 5). In the presence of $50 \mu \mathrm{M} \mathrm{H}_{2} \mathrm{O}_{2}$, mean zoospore settlement was greatly reduced on the TTIP/C8/TEOS coating (53\%) relative to the C8/TEOS coating (11\%, Figure 5). The difference in settlement between the two surfaces suggests that $\mathrm{H}_{2} \mathrm{O}_{2}$ activates the Ti-catalyst, which then discourages settlement of zoospores of $\mathrm{U}$. linza via the oxidation of halide salts on the coating surface to hypohalous acids. Increasing the $\mathrm{H}_{2} \mathrm{O}_{2}$ concentration to $100 \mu \mathrm{M}$ gave a slight additional reduction in settlement on both surfaces.

The halogenation of 1 shown in Figure 3 used concentrations of bromide and chloride much higher than those found in seawater and concentrations of $\mathrm{H}_{2} \mathrm{O}_{2} \quad 1000$-fold greater than the 50 $\mu \mathrm{M} \mathrm{H}_{2} \mathrm{O}_{2}$ used to discourage zoospore settlement in Figure 5. The lack of halogenation products from 1 under conditions that discouraged settlement of zoospores of $U$. linza suggest that hypohalous acids are not being produced in high concentrations in the bulk solution.

Some boundaries for hypohalous acid production by the TTIP/C8/TEOS xerogel surface can be established from the halogenation of phenol red (Figure 4). The inset of Figure 4a is a plot of the absorbance at $434 \mathrm{~nm}$ following the addition of incremental amounts of $\mathrm{HOCl}$ to phenol red. The slope of that line is $2.31 \times 10^{-3}$ absorbance units per $\mu \mathrm{M}$ bleach. Comparing Figure $4 \mathrm{~b}$ with 
Figure $4 \mathrm{c}$, the amount of bleach produced is equivalent to $\leq 5 \mu \mathrm{M}$ for an initial concentration of bleach (or $\leq 0.2 \mathrm{nmol} / \mathrm{mL} / \mathrm{h}$ of bleach produced in the coated cuvette). The data shown in Figure $7 \mathrm{a}$ give an $\mathrm{EC}_{50}$ of $\approx 150 \mu \mathrm{M}$ for a $50 \%$ reduction of zoospore settlement and an $\mathrm{EC}_{50}$ of $\approx 200$ $\mu \mathrm{M}$ for a $50 \%$ reduction in sporeling biomass. These results suggests that bulk hypohalous acid is not responsible for the reduction in zoospore settlement shown in Figure 5. Peroxide activation of Ti to a peroxotitanium(IV) species (Walker et al. 1997) and interaction of that species with halide can present a surface with a high oxidizing potential to discourage zoospore settlement.

Following zoospore settlement, there was no significant difference in 7-day-old sporeling biomass on the TTIP/C8/TEOS surfaces relative to the C8/TEOS control. In the presence of 50 $\mu \mathrm{M}$ hydrogen peroxide, less sporeling biomass was present on the TTIP/C8/TEOS surfaces relative to the C8/TEOS control, which may simply reflect the reduced settlement of zoospores on the TTIP/C8/TEOS surfaces. At $100 \mu \mathrm{M}$ hydrogen peroxide, the difference between the TTIP/C8/TEOS surface and the C8/TEOS control, while still significant, was reduced.

Enhanced FR characteristics in the presence of $\mathrm{H}_{2} \mathrm{O}_{2}$ were observed on the TTIP/C8/TEOS surface relative to the $\mathrm{C} 8 /$ TEOS surface. In the absence of $\mathrm{H}_{2} \mathrm{O}_{2}$, no significant difference in the removal of 7-day old sporelings was observed in comparing the C8/TEOS and TTIP/C8/TEOS coatings ( $32 \%$ removal from each, Figure 6 ). However, the removal of sporelings cultured in the presence of $50 \mu \mathrm{M}$ hydrogen peroxide was significantly greater from the TTIP/C8/TEOS coatings ( $52 \%$ removal) than from the control C8/TEOS coatings ( $23 \%$ removal). At $100 \mu \mathrm{M}$ $\mathrm{H}_{2} \mathrm{O}_{2}$, there was no longer a significant difference in the removal of sporeling biomass between the two surfaces $(45-50 \%$ removal). The latter observation suggests that high concentrations of $\mathrm{H}_{2} \mathrm{O}_{2}$ alone can impact adhesion. 
In conclusion, replacing TEOS in silica-derived xerogels with TTIP can provide "active" xerogel surfaces that use reagents found in seawater $\left(\mathrm{H}_{2} \mathrm{O}_{2}, 0.5 \mathrm{M}\right.$ chloride, $1 \mathrm{mM}$ bromide, and $1 \mu \mathrm{M}$ iodide) to reduce settlement of zoospores of $U$. linza. The "active" xerogel surface provides a chemical deterrent to the settlement of zoospores of $U$. linza and reduces the strength of adhesion of sporelings to the surface in the presence of $50 \mu \mathrm{M} \mathrm{H}_{2} \mathrm{O}_{2}$. This concentration of $\mathrm{H}_{2} \mathrm{O}_{2}$ can occur naturally under some conditions in the marine environment (Willey et al. 1999; Yuan and Shiller 2000; Le Bozek et al. 2001; Clark et al. 2008). Importantly, the titania/silica hybrid xerogels are the first to catalyze the oxidation of chloride with $\mathrm{H}_{2} \mathrm{O}_{2}$ and the oxidation of chloride occurs at $\mathrm{pH} 7.0$ and $\mathrm{pH}$ 8.0. In seawater, the 500-fold higher concentration of chloride relative to bromide provides a kinetic advantage for the oxidation of chloride.

The findings of this study indicate that replacing TEOS with TTIP in the xerogel formulations has minimal impact on xerogel surface characteristics and that the mixed titania/silica xerogels remain transparent and applicable via a variety of coating techniques. The $\mathrm{AF}$ and $\mathrm{FR}$ characteristics are observed at $\mathrm{pH} 8-$ the $\mathrm{pH}$ of seawater. This approach can be extended to balance AF and FR properties through the use of different loading levels of TTIP, as well as the use of different transition metal oxides (Morey et al. 2000), and through the use of different organo(trialkoxy)silanes for the coating matrix (Gunari et al. 2011; Sokolova et al. 2012; Sokolova et al. 2012a; Evariste et al. 2013).

\section{Acknowledgements}

SF/JAF/ASC (awards N00014-13-1-0633 and N00014-13-1-0634) and CAD/CMG/MRD (awards N00014-15-1-2400 and N00014-13-1-0430) thank the U. S. Office of Naval Research for partial support of these studies.

\section{References}


Alberto EE, Muller LM, Detty MR. 2015. Rate acceleration of bromination reactions with $\mathrm{NaBr}$ and $\mathrm{H}_{2} \mathrm{O}_{2}$ via the addition of catalytic quantities of diaryl ditellurides. Organometallics. 33: $5571-5581$.

Aldred N, Scardino A, Cavaco A, de Nys R, Clare AS. 2010. Attachment strength is a key factor in the selection of surfaces by barnacle cyprids (Balanus amphitrite) during settlement. Biofouling. 26: 287-299.

Almeida E, Diamantino TC, De Sousa O. 2007. Marine paints: The particular case of antifouling paints. Prog Org Coat. 59: 2-20.

Atlar M, Unal B, Unal UO, Politis G, Martinelli E, Galli G, Davies C, Williams D. 2013. An experimental investigation of the frictional drag characteristics of nanostructured and fluorinated fouling-release coatings using an axisymmetric body. Biofouling. 29: 39-52.

Avnir D. 1995. Organic chemistry within ceramic matrices: doped sol-gel materials. Acc Chem Res. 28: 328 - 341 .

Baier RE, Shafrin EG, Zisman WA. 1968. Adhesion: mechanisms that assist or impede it. Science. 162: 1360-8.

Baier RE, Meyer AE. 1992. Surface analysis of fouling-resistant marine coatings. Biofouling. 6: $165-180$.

Banerjee I, Pangule RC, Kane RS. 2011. Antifouling coatings: Recent developments in the design of surfaces that prevent fouling by proteins, bacteria, and marine organisms. Adv Mater. 23: 690-718.

Bennett SM, Tang Y, McMaster D, Bright FV, Detty MR. 2008. Active-site/surface cooperativity in xerogel-sequestered selenoxide catalysts for the activation of hydrogen peroxide in an aqueous environment. J Org Chem. 73: 6849-6853. 
Bennett SM, Finlay JA, Gunari N, Wells DD, Meyer AE, Walker GC, Callow ME, Callow JA, Bright FV, Detty MR. 2010. The role of surface energy and water wettability in aminoalkyl/fluorocarbon/hydrocarbon-modified xerogel surfaces in the control of marine biofouling. Biofouling. 26: 235-246.

Borghi V, Porte C. 2002. Organotin pollution in deep-sea fish from the Northwestern Mediterranean. Environ Sci Technol. 36: 4224-4228.

Brinker CJ, Scherer GW. 1990. Sol-gel science: the physics and chemistry of sol-gel processing. New York: Academic Press.

Callow ME, Callow JA, Pickett-Heaps JD, Wetherbee R. 1997. Primary adhesion of Enteromorpha (Chlorophyta, Ulvales) propagules: quantitative settlement studies and video microscopy. J Phycol. 33: 938-947.

Chambers LD, Stokes KR, Walsh FC, Wood RJK. 2006. Modern approaches to marine antifouling coatings. Surf Coat Technol. 201: 3642-3652.

Ciriminna R, Bright FV, Pagliaro M. 2015. Ecofriendly antifouling marine coatings. ACS Sustainable Chem Eng. 3: 559-565.

Clark CD, De Bruyn WJ, Jakubowski SD, Grant SB. 2008. Hydrogen peroxide production in marine bathing waters: implications for fecal indicator bacteria mortality. Mar Pollut Bull. 56: $397-401$.

Cooper WJ, Zika RG. 1983. Photochemical formation of hydrogen peroxide in surface and ground waters exposed to sunlight. Science. 220: 771-712.

Dave BC, Soyez H, Miller JM, Dunn B, Valentine JS, Zink JI. 1995. Synthesis of proteindoped sol-gel $\mathrm{SiO} 2$ thin films: evidence for rotational mobility of encapsulated cytochrome c. Chem Mater. 7:1431 - 1434. 
Detty MR, Ciriminna R, Bright FV, Pagliaro M. 2014. Environmentally benign sol-gel antifouling and foul-releasing coatings. Acc Chem Res. 47: 678-687.

Drabkova M. 2007. Selective effects of hydrogen peroxide on cyanobacteria photosynthesis. Photosynthetica. 45: 363-369.

Evariste E, Gatley CM, Detty MR, Callow ME, Callow JA. 2013. The performance of aminoalkyl/fluorocarbon/hydrocarbon-modified xerogel coatings against the marine alga Ectocarpus crouaniorum: relative roles of surface energy and charge. Biofouling. 29: 171-184.

Gatley CM, Muller LM, Lang MA, Alberto EE, Detty MR. 2015. Xerogel-sequestered silanated organochalcogenide catalysts for bromination with hydrogen peroxide and sodium bromide. Molecules. 20: 9616-9639.

Genovese S, Epifano F, Pelucchini C, Procopio A, Curini M. 2010. Ytterbium triflate catalyzed synthesis of chlorinated lactones. Tetrahedron Lett. 51: 5992-5995.

Goodman MA, Detty MR. 2004. Selenoxides as catalysts for the activation of hydrogen peroxide. Bromination of organic substrates with sodium bromide and hydrogen peroxide. Organometallics. 23: 3016-3020.

Gunari N, Brewer LH, Bennett SM, Sokolova A, Kraut ND, Finlay JA, Meyer AE, Walker GC, Wendt DE, Callow ME, Wendt DE, Callow ME, Callow JA, Bright FV, Detty MR. 2011. The control of marine biofouling on xerogel surfaces with nanometer-scale topography. Biofouling. 27:137-149.

Ingersoll CM, Bright FV. 1997. Using sol-gel-based platforms for chemical sensors. Chemtech. 27: $26-35$.

Jack TR. 1999. Monitoring microbial fouling and corrosion problems in industrial systems. Corros Rev. 17: 1-31. 
Le Bozec N, Compere C, L'Her M, Laouenan A, Costa D, Marcus P. 2001. Influence of stainless steel surface treatment on the oxygen reduction reaction in seawater. Corrosion Sci. 43: 765-786.

Lejars M, Margaillan A, Bressy C. 2012. Fouling release coatings: A nontoxic alternative to biocidal antifouling coatings. Chem Rev. 112: 4347-4390.

Martinelli E, Agostini S, Galli G, Chiellini E, Glisenti A, Pettit ME, Callow ME, Callow JA, Graf K, Bartels FW. 2008. The surface-segregate nanostructure of fluorinated copolymerpoly(dimethylsiloxane) blend films. Langmuir. 24:13138-13147.

McMaster DM, Bennett SM, Tang Y, Finlay JA, Kowalke GL, Nedved B, Bright FV, Callow ME, Callow JA, Wendt DE, Hadfield MG, Detty MR. 2009. Antifouling character of 'active' hybrid xerogel coatings with sequestered catalysts for the activation of hydrogen peroxide. Biofouling. 25: 21-33.

Mohammad A, Liebhafsky HA. 1934. The kinetics of the reduction of hydrogen peroxide by the halides. J Am Chem Soc. 56: 1680-1685.

Morey MS, Bryan JD, Schwarz S, Stucky GD. 2000. Pore surface functionalization of MCM48 mesoporous silica with tungsten and molybdenum metal centers: perspectives on catalytic peroxide activation. Chem Mater. 12: 3435-3444.

Natalio F, Andre R, Hartog AF, Stoll B, Jochum KP, Wever R, Tremel W. 2012. Vanadium pentoxide nanoparticles mimic vanadium haloperoxidases and thwart biofilm formation. Nat Nanotechnol. 7: 530-535.

Owens DK, Wendt RC. 1969. Estimation of the surface free energy of polymers. J Appl Polym Sci 13: 1741-1747. 
Pagliaro M, Ciriminna R, Palmisano G. 2009. Silica-based hybrid coatings. J Mater Chem. 19: 3116-3126.

Rosenhahn A, Schilp S, Kreuzer HJ, Grunze M. 2010. The role of "inert" surface chemistry in marine biofouling prevention. Phys Chem Chem Phys. 12: 4275-4286.

Schultz MP. 2007. Effects of coating roughness and biofouling on ship resistance and powering. Biofouling. 23: 331-341.

Schultz MP, Bendick JA, Holm ER, Hertel WM. 2011. Economic impact of biofouling on a naval surface ship. Biofouling. 27: 87-98.

Sokolova A, Cilz N, Daniels J, Stafslien SJ, Brewer LH, Wendt DE, Bright FV, Detty MR. 2012. A comparison of antifouling/foul-release characteristics of non-biocidal xerogel and commercial coatings toward micro- and macrofouling organisms. Biofouling. 28: 511-523.

Sokolova A, Bailey JJ, Brewer LH, Finlay JA, Fornalik J, Wendt DE, Callow ME, Callow JA, Bright FV, Detty MR. 2012a. Spontaneous multiscale phase separation within fluorinated xerogel coatings for fouling-release surfaces. Biofouling. 28: 143-157.

Tang Y, Finlay JA, Kowalke GL, Meyer AE, Bright FV, Callow ME, Callow JA, Wendt DE, Detty MR. 2005. Hybrid xerogel films as novel coatings for antifouling and fouling release. Biofouling. 21: 59-71.

Walker JV, Morey M, Carlsson M, Davidson A, Stucky GD, Butler A. 1997. Peroxidative halogenation catalyzed by transition-metal-ion-grafted mesoporous silicate materials. J Am Chem Soc. 119: 6921-6922.

Willey JD, Paerl HW, Go M. 1999. Impact of rainwater hydrogen peroxide on chlorophyll a content of surface Gulf Stream seawater off North Carolina, USA. Mar Ecol Prog Ser. 178: 145150. 
Williams SL, Schroeder SL 2004. Eradication of the invasive seaweed Caulerpa taxifolia by chlorine bleach. Mar Ecol Prog Ser. 272: 69-76.

Yuan J, Shiller AM. 2000. The variation of hydrogen peroxide in rain water over the South and Central Atlantic Ocean. Atm Environ. 34: 3973-3980.

Yuan J, Shiller AM. 2001. The distribution of hydrogen peroxide in the southern and central Atlantic Ocean. Deep Sea Res II. 48: 2947-2970. 
Table 1: Contact angles and surface energies of xerogel coatings.

\begin{tabular}{|c|c|c|c|c|}
\hline $\begin{array}{l}\text { Composition } \\
\text { /Name }\end{array}$ & $\begin{array}{l}100 \\
\text { TEOS }\end{array}$ & $\begin{array}{c}\text { 20:80 } \\
\text { TTIP/TEOS }\end{array}$ & $\begin{array}{c}\text { 40:60 } \\
\text { C8/TEOS }\end{array}$ & $\begin{array}{c}\text { 20:40:40 } \\
\text { TTIP/C8/TEOS }\end{array}$ \\
\hline \multicolumn{5}{|c|}{ Stored in Air } \\
\hline $\begin{array}{c}\text { Static Water Contact Angle } \\
\left(\theta_{\mathrm{Ws}_{\mathrm{s}}}{ }^{\circ}\right)\end{array}$ & $44 \pm 2$ & $45 \pm 4$ & $102.8 \pm 0.6$ & $99 \pm 1$ \\
\hline $\begin{array}{c}\text { Static } \mathrm{CH}_{2} \mathrm{I}_{2} \text { Contact Angle } \\
\left(\boldsymbol{\theta}_{\left.(\mathrm{CH} 2 \mathrm{I} 2) \mathrm{s}^{\circ}\right)}{ }^{\circ}\right.\end{array}$ & $46 \pm 2$ & $37 \pm 1$ & $69 \pm 1$ & $66 \pm 1$ \\
\hline $\begin{array}{l}\text { Total Surface Energy } \gamma_{\mathrm{S}} \\
(\mathrm{mN} \mathrm{m}-1)\end{array}$ & $56 \pm 2$ & $57 \pm 2$ & $23.2 \pm 0.2$ & $25.0 \pm 0.1$ \\
\hline \multicolumn{5}{|c|}{ Immersed $24 \mathrm{~h}$ in ASW Water } \\
\hline $\begin{array}{c}\text { Static Water Contact Angle } \\
\left(\theta_{\mathrm{Ws}_{\mathrm{s}}}{ }^{\circ}\right)\end{array}$ & $31 \pm 1$ & $35 \pm 4$ & $99.4 \pm 0.8$ & $94 \pm 2$ \\
\hline $\begin{array}{c}\text { Static } \mathrm{CH}_{2} \mathbf{I}_{2} \text { Contact Angle } \\
\left(\boldsymbol{\theta}_{\left.(\mathrm{CH} 2 \mathrm{I} 2) \mathrm{s}^{\circ}\right)}{ }^{\circ}\right.\end{array}$ & $47 \pm 1$ & $40 \pm 2$ & $65 \pm 1$ & $63 \pm 1$ \\
\hline $\begin{array}{c}\text { Total Surface Energy } \gamma_{\mathrm{s}} \\
\left(\mathrm{mN} \mathrm{m}^{-1}\right)\end{array}$ & $63.9 \pm 0.6$ & $62 \pm 2$ & $26 \pm 1$ & $27 \pm 1$ \\
\hline
\end{tabular}

${ }^{a}$ Values are the average of 3 replicate runs (6 measurements) ${ }^{a}$ Error limits are \pm one standard deviation. 
Table 2. Rates of halogenation of 4-pentenoic acid (1) with $\mathrm{H}_{2} \mathrm{O}_{2}$ and sodium halide salts at pH 7 or pH 8 and $298 \pm 1 \mathrm{~K}$ in the presence of xerogel catalysts.

\begin{tabular}{cccccc}
\hline entry & Xerogel & $\begin{array}{c}\text { Ti, mole- } \\
\mathbf{\%}\end{array}$ & $\mathbf{p H}$ & $\boldsymbol{k}_{\text {obs }}, \mathbf{s}^{-\mathbf{1}}$ & $\boldsymbol{k}_{\text {rel }}$ \\
\hline & & & Bromination & & \\
\hline $\mathbf{1}$ & $100 \mathrm{TEOS}$ & 0 & 7.0 & $(2.47 \pm 0.15) \times 10^{-7 a}$ & 1 \\
$\mathbf{2}$ & $20: 80 \mathrm{TTIP} / \mathrm{TEOS}$ & 3.5 & 7.0 & $(8.44 \pm 0.10) \times 10^{-5 a}$ & 340 \\
$\mathbf{3}$ & $40: 60 \mathrm{C} 8 / \mathrm{TEOS}$ & 0 & 7.0 & $(5.94 \pm 0.05) \times 10^{-7 a}$ & 2.4 \\
$\mathbf{4}$ & $20: 40: 40 \mathrm{TTIP} / \mathrm{C} 8 / \mathrm{TEOS}$ & 3.5 & 7.0 & $(3.37 \pm 0.09) \times 10^{-6 a}$ & 14 \\
$\mathbf{5}$ & $100 \mathrm{TEOS}$ & 0 & 8.0 & $(7.34 \pm 0.44) \times 10^{-7 a}$ & 3 \\
$\mathbf{6}$ & $20: 40: 40 \mathrm{TTIP} / \mathrm{C} 8 / \mathrm{TEOS}$ & 3.5 & 8.0 & $(1.36 \pm 0.11) \times 10^{-6 a}$ & 5.5 \\
\hline & & & Chlorination & & 1 \\
\hline $\mathbf{5}$ & $100 \mathrm{TEOS}$ & 0 & 7.0 & $(1.48 \pm 0.27) \times 10^{-7 b}$ & 1 \\
$\mathbf{7}$ & $20: 80 \mathrm{TTIP} / \mathrm{TEOS}$ & 60 & 7.0 & $(1.51 \pm 0.05) \times 10^{-5 a}$ & 100 \\
$\mathbf{8}$ & $40: 60 \mathrm{C} 8 / \mathrm{TEOS}$ & 0 & 7.0 & $(2.00 \pm 0.11) \times 10^{-7 a}$ & 1.4 \\
$\mathbf{9}$ & $20: 40: 40 \mathrm{TTIP} / \mathrm{C} 8 / \mathrm{TEOS}$ & 20 & 7.0 & $(1.03 \pm 0.05) \times 10^{-6 a}$ & 5.4 \\
$\mathbf{1 0}$ & $20: 40: 40 \mathrm{TTIP} / \mathrm{C} 8 / \mathrm{TEOS}$ & 60 & 7.0 & $(3.22 \pm 0.62) \times 10^{-6 b}$ & 22 \\
$\mathbf{6}$ & $100 \mathrm{TEOS}$ & 0 & 8.0 & $(7.20 \pm 0.39) \times 10^{-8 b}$ & 0.5 \\
$\mathbf{1 1}$ & $20: 40: 40 \mathrm{TTIP} / \mathrm{C} 8 / \mathrm{TEOS}$ & 60 & 8.0 & $(1.46 \pm 0.65) \times 10^{-6 b}$ & 9.9 \\
\hline & & & & & \\
\hline
\end{tabular}

${ }^{a}$ Values are the average of duplicate runs. Error limits are \pm one half of the range. ${ }^{b}$ Values are the average of triplicate runs. Error limits are \pm one standard deviation. 


\section{Figure Captions}

Figure 1. SEM images of the TTIP/C8/TEOS xerogel a) from above and b) along an edge stored in air and c) from above and d) along an edge post-immersion in ASW.

Figure 2. Changes in the TTIP/C8/TEOS xerogel pre- and post-immersion in DI water or 200 $\mu \mathrm{M} \mathrm{H}_{2} \mathrm{O}_{2}$ as determined by XPS. Mean of four independent measurements for coatings either pre-immersion or post-immersion for 24 in DI water or $24 \mathrm{~h}$ in $200 \mu \mathrm{M} \mathrm{H}_{2} \mathrm{O}_{2}$. Error bars represent $1 \mathrm{SD}$ for the four independent measurements for the three conditions.

Figure 3. a) Rate of bromination of $1(\ln [\mathrm{A}]$ vs. time, where $A$ is the concentration of $\mathbf{1})$ with 1.4 $\mathrm{M} \mathrm{NaBr}$ and $0.21 \mathrm{M} \mathrm{H}_{2} \mathrm{O}_{2}$ comparing the TTIP/TEOS (filled circles), TTIP/C8/TEOS (Filled triangles), and TEOS xerogels (open circles) as catalysts at $298 \pm 1 \mathrm{~K}$ at $\mathrm{pH} 7 \mathrm{or}$ b) at $\mathrm{pH} 8$. All points represent the average of duplicate runs and error bars represent the range of values. C) Rate of chlorination of 1 with $2.7 \mathrm{M} \mathrm{NaCl}$ and $0.68 \mathrm{M} \mathrm{H}_{2} \mathrm{O}_{2}$ comparing the TTIP/TEOS (filled circles), TTIP/C8/TEOS (Filled triangles), and TEOS xerogels (open circles) as catalysts at pH 7 or d) at $\mathrm{pH} 8$. All reactions were run at $298 \pm 1 \mathrm{~K}$. All points represent the average of triplicate runs and error bars represent $\pm 1 \mathrm{SD}$.

Figure 4. Halogenation of $50 \mu \mathrm{M}$ phenol red in ASW a) via the incremental addition of bleach $(\mathrm{HOCl})$ to give the equivalent of the concentrations shown with b) an expansion of the 400-450nm region or c) via the addition of $50 \mu \mathrm{M} \mathrm{H} \mathrm{H}_{2} \mathrm{O}_{2}$ in the glass cuvette coated with the TTIP/C8/TEOS xerogel with d) an expansion of the 400-450-nm region. The inset of a) shows a plot of the initial absorbance at $434 \mathrm{~nm}$ minus the absorbance at time, $t$, plotted against the equivalent concentration of bleach. The slope of the line gives the change in absorbance per $\mu \mathrm{M}$ bleach. 
Figure 5. The density of attached spores on C8/TEOS and TTIP/C8/TEOS coatings after 45-min settlement time in the presence of different concentrations of $\mathrm{H}_{2} \mathrm{O}_{2}$. Each point is the mean from 90 counts on 3 replicate slides. Bars show 95\% confidence limits. Values of the bars that share a letter are not significantly different $(p>0.05)$ from one another.

Figure 6. a) Biomass of sporelings on C8/TEOS and TTIP/C $8 /$ TEOS coatings after $7 \mathrm{~d}$. Each point is the mean biomass from 6 replicate slides measured using a fluorescence plate reader (RFU; relative fluorescence unit). b) Percent removal of 7-day-old sporelings from coatings due to an impact pressure of $30 \mathrm{kPa}$. Each point is the mean removal of biomass from 6 replicate slides measured using a fluorescence plate reader. Bars show standard error of the mean determined from arcsine transformed data. Values of the bars that share a letter are not significantly different $(p>0.05)$ from one another.

Figure 7. The impact of sodium hypochlorite on the settlement of zoospores and growth of sporelings of $U$. linza. a) The density of attached spores after 45 -min settlement time in the presence of a range of concentrations of sodium hypochlorite. Each point is the mean from 90 counts on 3 replicate slides. b) The biomass of sporelings after 7-days growth in the presence of sodium hypochlorite. Each point is the mean biomass from 4 replicate wells measured using extracted chlorophyll in a fluorescence plate reader (RFU; relative fluorescence unit). Bars show $95 \%$ confidence limits. 


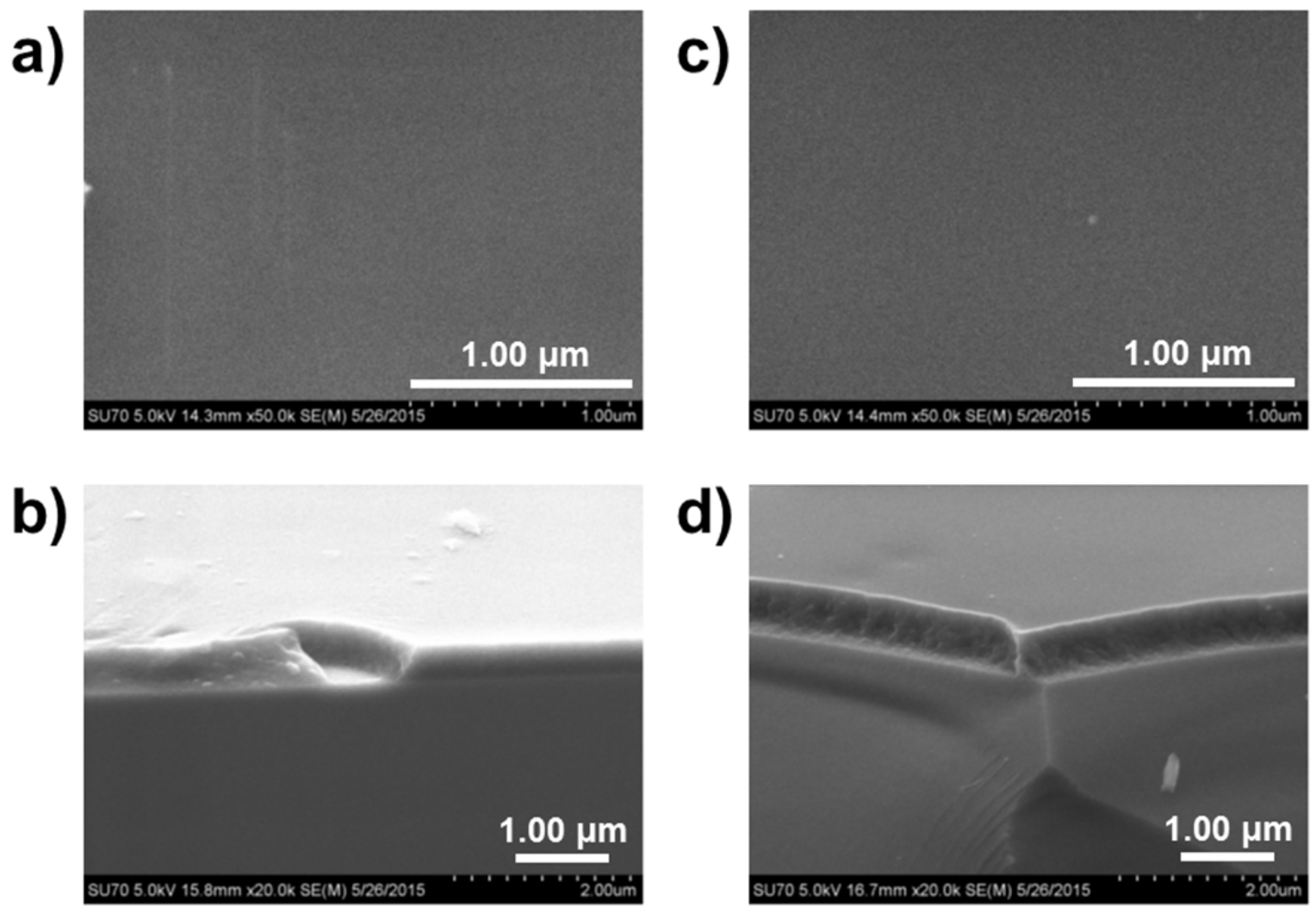

Figure 1. SEM images of the TTIP/C8/TEOS xerogel a) from above and b) along an edge stored in air and c) from above and d) along an edge post-immersion in ASW. 


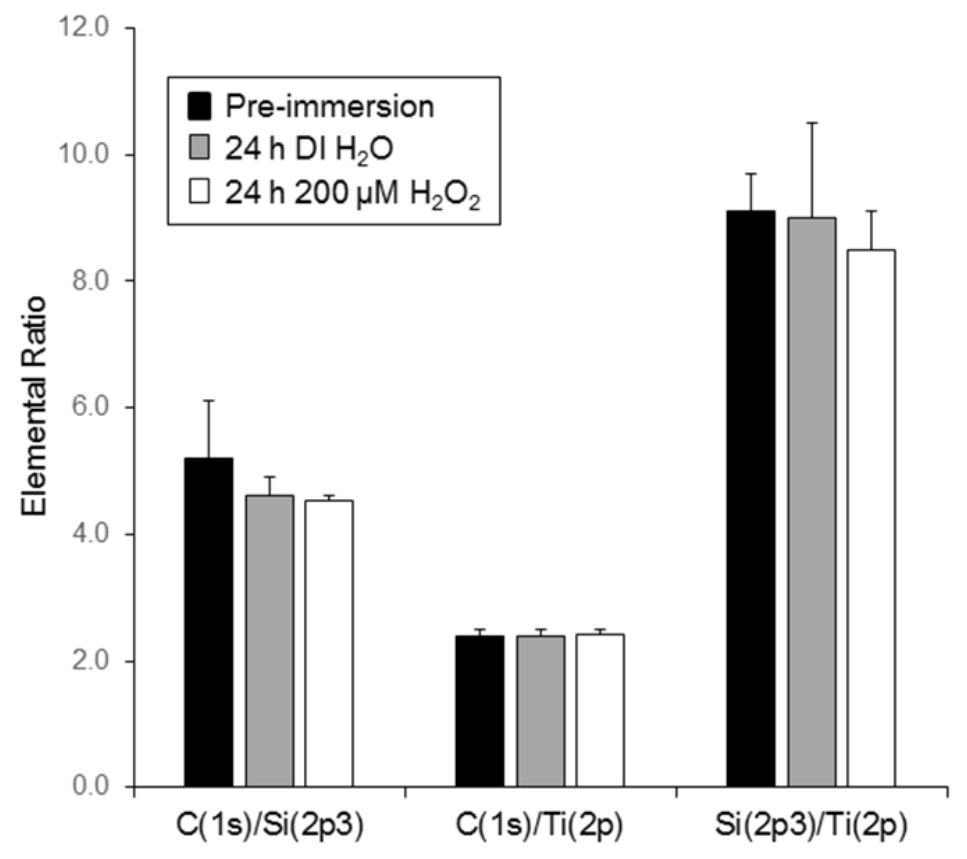

Figure 2. Changes in the TTIP/C8/TEOS xerogel pre- and post-immersion in DI water or 200 $\mu \mathrm{M} \mathrm{H} \mathrm{H}_{2} \mathrm{O}_{2}$ as determined by XPS. Mean of four independent measurements for coatings either pre-immersion or post-immersion for 24 in DI water or $24 \mathrm{~h}$ in $200 \mu \mathrm{M} \mathrm{H}_{2} \mathrm{O}_{2}$. Error bars represent $1 \mathrm{SD}$ for the four independent measurements for the three conditions. 

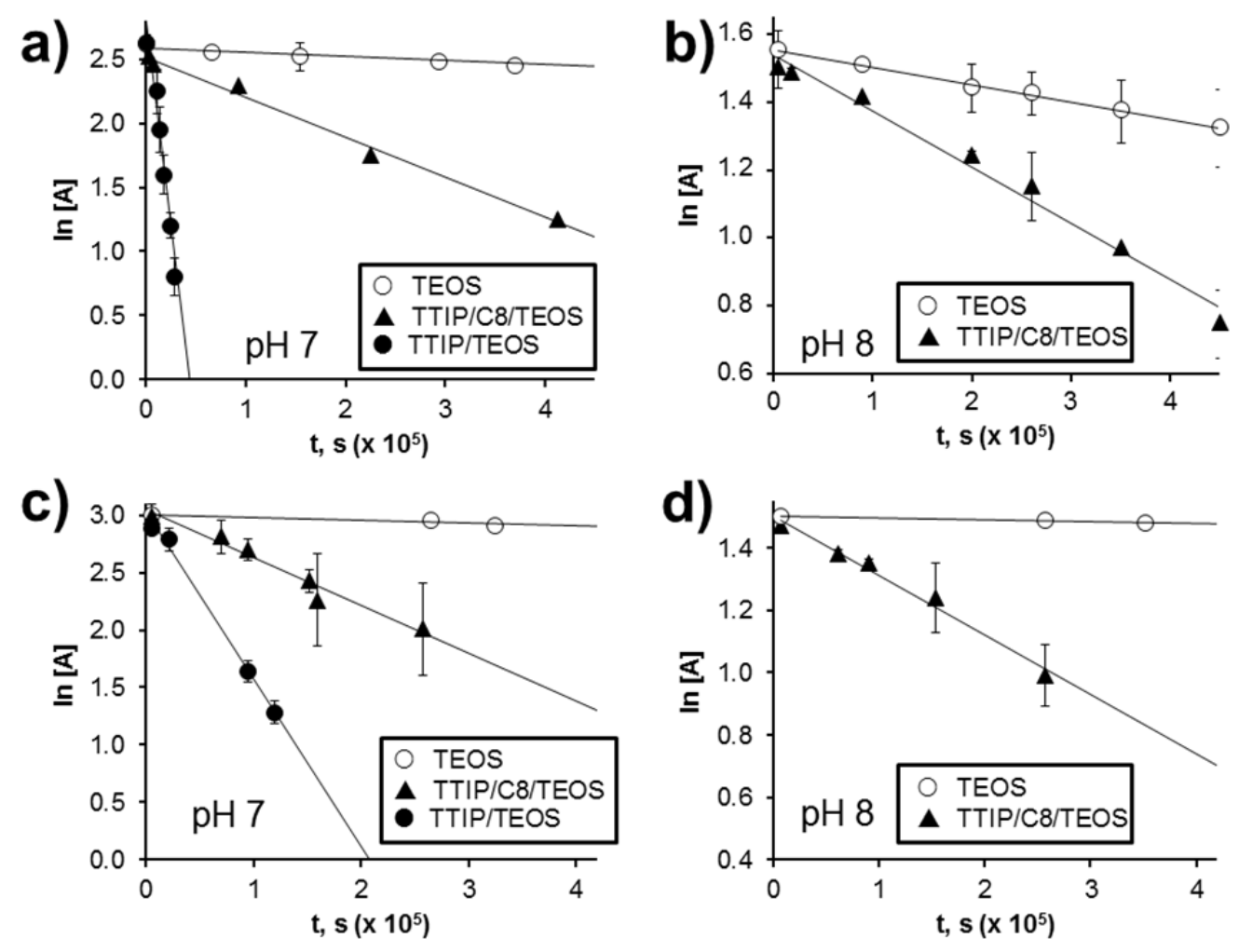

Figure 3. a) Rate of bromination of $\mathbf{1}(\ln [\mathrm{A}]$ vs. time, where $\mathrm{A}$ is the concentration of $\mathbf{1})$ with 1.4 $\mathrm{M} \mathrm{NaBr}$ and $0.21 \mathrm{M} \mathrm{H}_{2} \mathrm{O}_{2}$ comparing the TTIP/TEOS (filled circles), TTIP/C8/TEOS (Filled triangles), and TEOS xerogels (open circles) as catalysts at $298 \pm 1 \mathrm{~K}$ at $\mathrm{pH} 7 \mathrm{or} \mathrm{b}$ ) at $\mathrm{pH} 8$. All points represent the average of duplicate runs and error bars represent the range of values. C) Rate of chlorination of 1 with $2.7 \mathrm{M} \mathrm{NaCl}$ and $0.68 \mathrm{M} \mathrm{H}_{2} \mathrm{O}_{2}$ comparing the TTIP/TEOS (filled circles), TTIP/C8/TEOS (Filled triangles), and TEOS xerogels (open circles) as catalysts at pH 7 or d) at $\mathrm{pH}$ 8. All reactions were run at $298 \pm 1 \mathrm{~K}$. All points represent the average of triplicate runs and error bars represent $\pm 1 \mathrm{SD}$. 

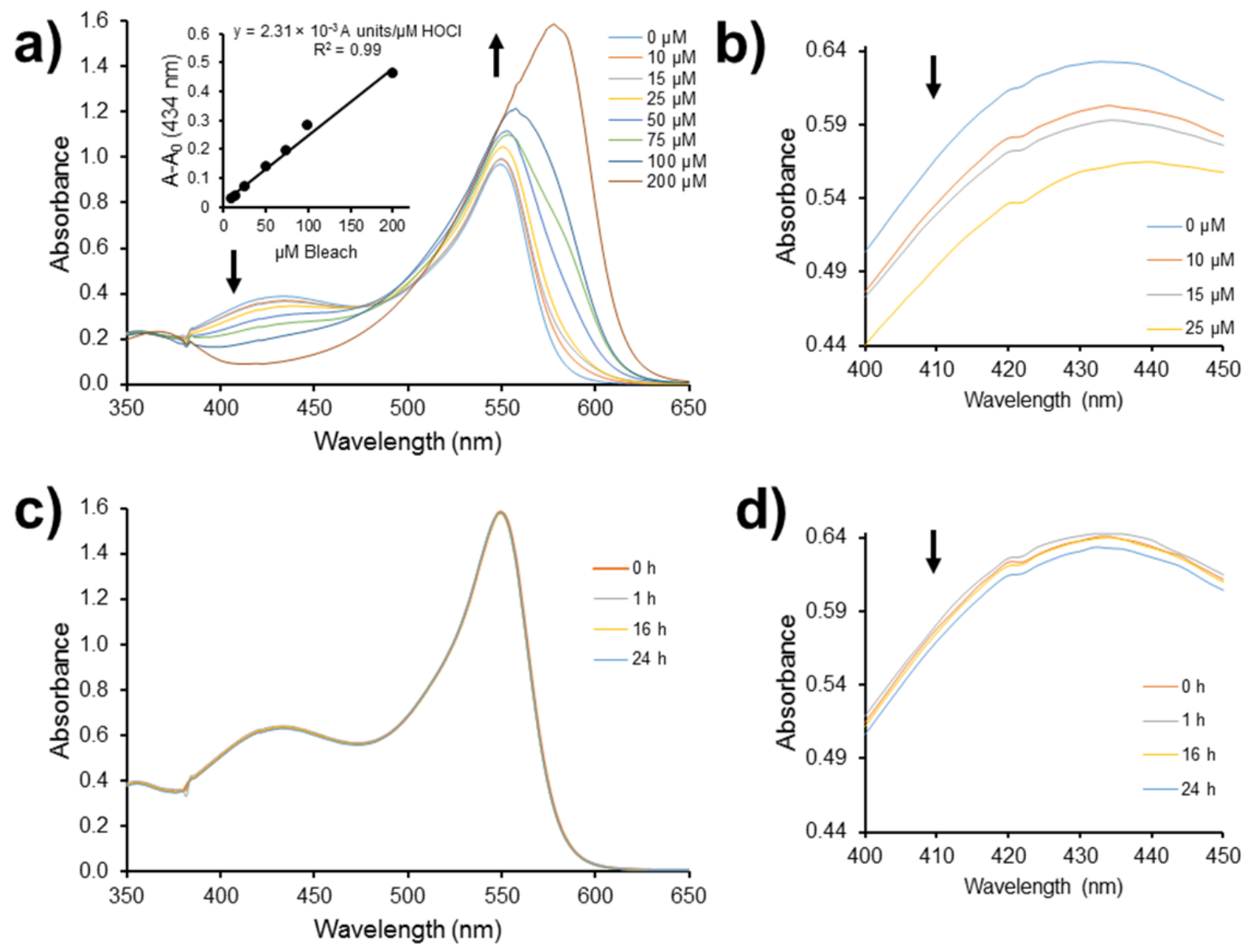

Figure 4. Halogenation of $50 \mu \mathrm{M}$ phenol red in ASW a) via the incremental addition of bleach (HOCl) to give the equivalent of the concentrations shown with b) an expansion of the 400-450$\mathrm{nm}$ region or c) via the addition of $50 \mu \mathrm{M} \mathrm{H} \mathrm{H}_{2} \mathrm{O}_{2}$ in the glass cuvette coated with the TTIP/C8/TEOS xerogel with d) an expansion of the 400-450-nm region. The inset of a) shows a plot of the initial absorbance at $434 \mathrm{~nm}$ minus the absorbance at time, $t$, plotted against the equivalent concentration of bleach. The slope of the line gives the change in absorbance per $\mu \mathrm{M}$ bleach. 


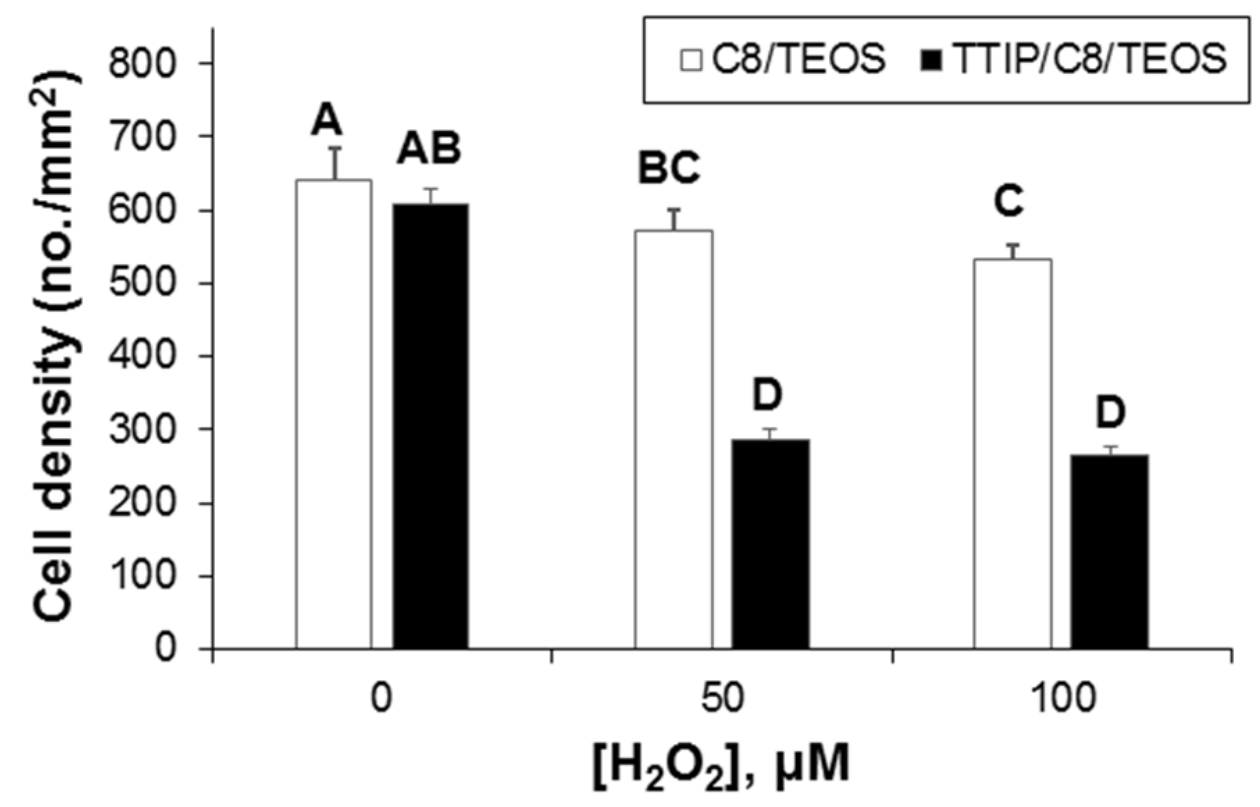

Figure 5. The density of attached spores on C8/TEOS and TTIP/C8/TEOS coatings after 45-min settlement time in the presence of different concentrations of $\mathrm{H}_{2} \mathrm{O}_{2}$. Each point is the mean from 90 counts on 3 replicate slides. Bars show $95 \%$ confidence limits. Values of the bars that share a letter are not significantly different $(p>0.05)$ from one another. 

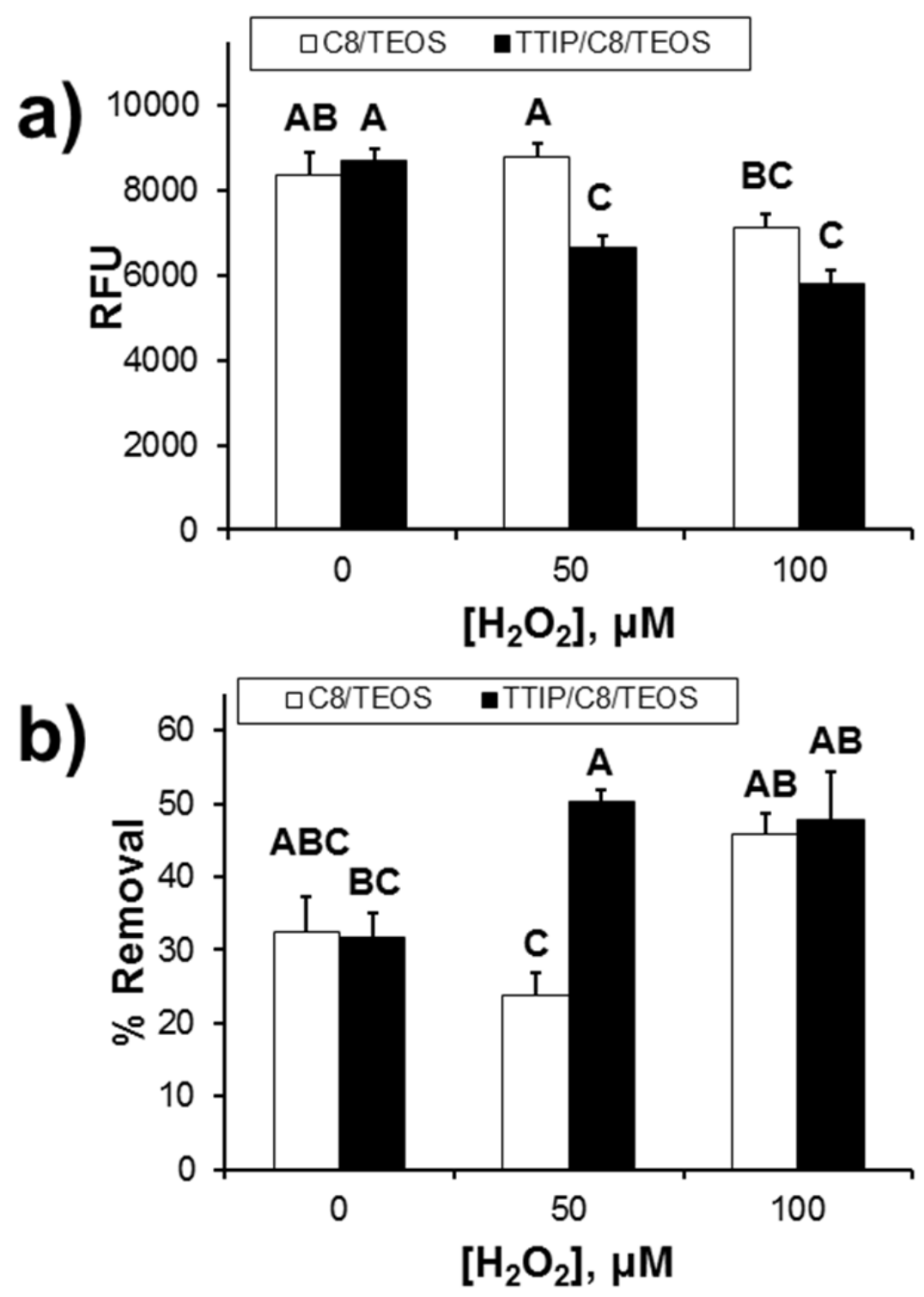

Figure 6. a) Biomass of sporelings on C8/TEOS and TTIP/C8/TEOS coatings after $7 \mathrm{~d}$. Each point is the mean biomass from 6 replicate slides measured using a fluorescence plate reader (RFU; relative fluorescence unit). b) Percent removal of 7-day-old sporelings from coatings due to an impact pressure of $30 \mathrm{kPa}$. Each point is the mean removal of biomass from 6 replicate slides measured using a fluorescence plate reader. Bars show standard error of the mean determined from arcsine transformed data. Values of the bars that share a letter are not significantly different $(p>0.05)$ from one another. 

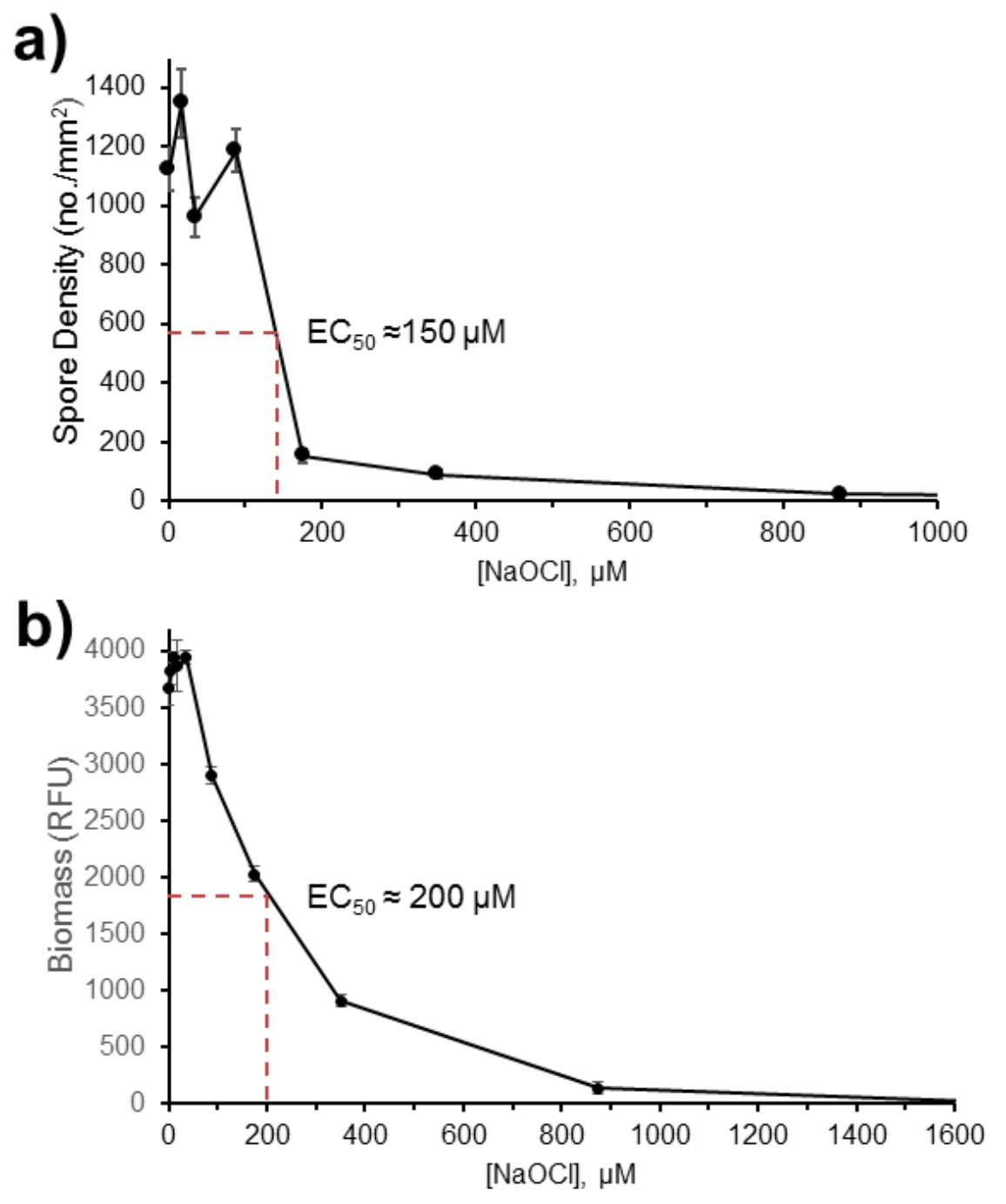

Figure 7. The impact of sodium hypochlorite on the settlement of zoospores and growth of sporelings of $U$. linza. a) The density of attached spores after 45 -min settlement time in the presence of a range of concentrations of sodium hypochlorite. Each point is the mean from 90 counts on 3 replicate slides. b) The biomass of sporelings after 7-days growth in the presence of sodium hypochlorite. Each point is the mean biomass from 4 replicate wells measured using extracted chlorophyll in a fluorescence plate reader (RFU; relative fluorescence unit). Bars show $95 \%$ confidence limits. 